\title{
Правовой статус тувинских женщин сквозь призму законов Тувинской Народной Республики
}

\author{
Органа Д. Натсак \\ Тувинский институт гуманитарных и прикладных социально-экономических исследований \\ при Правительстве Республики Тыва, Российская Федерация
}

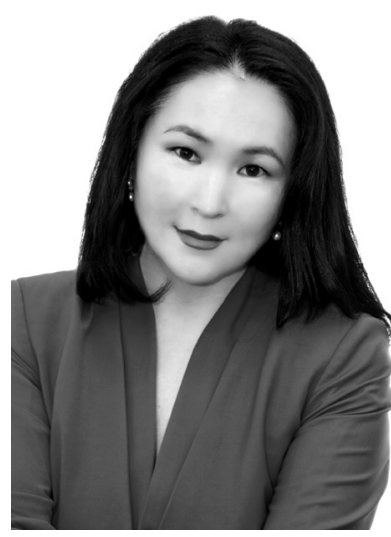

В статье анализируется эволюция конституционного, гражданско-правового положения тувинских женщин сквозь призму законов Тувинской Народной Республики. Предпринята попытка определения генезиса отдельных норм законодательства в отношении женщин, сделан сравнительный анализ с советским законодательством с учетом социильных, культурных и политических факторов в тувинском обществе. Источниковую базу исследования составили конституции, уголовные и гражданские законы ТНР, в которых отражена политико-правовая основа эмансипации тувинских женщин.

Правовым ориентиром для ТНР стал законотворческий опыт СССР, в тувинских законах прослеживается прямая рецепция отдельных норм советских законов. Вместе с тем при разработке законов учитывалась социокультурная, общественно-политическая спеццифика ТНР.

Конституции ТНР дали женщинам политические права, гражданские свободы, конституционно закрепленное равноправие с мужчинами, доступ к управлению государством, образованию, современному здравоохранению. Однако конституционного признания равноправия с мужчинами было недостаточно. Для реального изменения статусно-ролевой функции женщин, политической социализации и включения женщин в экономику страны, было необходимо принятие ряда норм в уголовных, гражданских законах ТНР. Поэтому отдельному разбору в исследовании подверглись уголовные и гражданские законы.

Уголовные законы ТНР наложили запрет на физическое насилие над женщиной, насильственные браки, раннее замужество, привлечение женщины к занятию проституцией. Были введены новая форма регистрации брака, договорное и судебное регулирование имущественных правоотношений супругов при разводе, имущественных отношений при незарегистрированном сожительстве, практика установления отцовства, обязанности биологического отиа ребенка, рожденного вне брака. Законы о труде ТНР ввели дифференцированный подход к труду мужчин и женщин, женский труд получил определенные льготы в связи с выполнением репродуктивных функций женщин. Женский труд был включен в производственные отношения, экономику государства. Возникает новый тип работающей по найму женщины с гарантированной государством оплатой труда и трудовыми правами.

Заключается, что в совокупности и конституции, и уголовные, гражданские законы ТНР явились политико-правовой базой для эмансипации тувинской женщины.

Ключевые слова: Тувинская Народная Республика; Тува; тувинцы; история Тувы; равноправие; правовой статус женщин, эмансипация; права женщин

Для цитирования:

Натсак О. Д. Правовой статус тувинских женщин сквозь призму законов Тувинской Народной Республики // Новые исследования Тувы. 2021, № 1. C. 148-173. DOI: https://www.doi.org/10.25178/nit.2021.1.8

\footnotetext{
Натсак Органа Доржуевна - кандидат философских наук, ученый секретарь Тувинского института гуманитарных и прикладных социально-экономических исследований при Правительстве Республики Тыва. Адрес: 667000, Россия, г. Кызыл, ул. Кочетова, д. 4. Тел.: + 7 (394-22) 2-39-36. Эл. адрес: nod695596@gmail.com
}

NATSAK, Organa Dorzhuevna, Candidate of Philosophy, Academic Secretary, Tuvan Institute of Humanities and Applied Social and Economic Research under the Government of the Republic of Tuva. Postal address: 4 Kochetov St., 667000 Kyzyl, Russian Federation. Tel.: + 7 (394-22) 2-39-36. E-mail: nod695596@gmail.com 


\title{
The legal status of Tuvan women through the prism of the Laws of the Tuvan People's Republic
}

\author{
Organa D. Natsak \\ Tuvan Institute of Humanities and Applied Social and Economic Research under the Government of the Republic of Tuva, \\ Russian Federation
}

The article analyzes the evolution of the constitutional, civil and legal status of Tuvan women through the prism of the laws of the Tuvan People's Republic (TPR), attempts to determine the genesis of certain norms of women-related legislation through a comparative analysis with Soviet legislation. The article also considers social, cultural, and political factors in the life of the Tuvan society. For its sources, the study relies on the constitutions, criminal and civil laws of the TPR, which formed the political and legal basis for the emancipation of Tuvan women.

The legislative experience of the USSR was the legal guidance for the TPR, and the Tuvan laws directly borrowed certain norms of Soviet laws. At the same time, the socio-cultural and socio-political specifics of the TPR were also taken into account in the course of lawmaking.

The constitutions of the TPR endowed women with political rights, civil liberties, constitutionally guaranteed equality with men, access to government, education, and modern healthcare. However, for the emancipation of women, constitutional recognition of equality with men was not enough. To transform the status and role function of women, to provide political socialization and inclusion of women in the country's economy, it was necessary to add a number of provisions to the criminal and civil laws of the TPR, which thus explains our separate focus on these areas of legislation.

Criminal laws of TPR prohibited physical abuse of women, forced and early marriages, and involvement in prostitution. A new form of marriage registration was implemented, as well as contractual and judicial regulation of property relations between spouses in case of divorce, and property relations in case of unregistered cohabitation. Also introduced were the practice of paternity identification and duties of the biological father to a child born out of wedlock. The labor laws of the TPR introduced a differentiated approach to the labor of men and women. Women's labor received certain benefits due to women's reproductive functions, and made part of industrial relations and the state economy. There finally appears a new type of a working woman, the one enjoying state-guaranteed salary and labor rights.

It is concluded that both the Constitutions and the criminal and civil laws of the TPR were the political and legal basis for the emancipation of the Tuvan woman.

Keywords: Tuvan People's Republic, Tuva; Tuvans; Tuvan history; equal rights; women's legal status; emancipation; women's rights

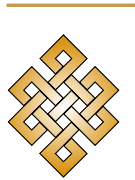

\section{For citation:}

Natsak O. D. The legal status of Tuvan women through the prism of the Laws of the Tuvan People's Republic. New Research of Tuva, 2021, no. 1, pp. 148-173. (In Russ.). DOI: https://www.doi.org/10.25178/nit.2021.1.8

\section{Введение}

В тувинской историографии неизученными остаются вопросы, связанные с правовым положением женщин в Тувинской Народной Республике (далее - ТНР) (1921-1944), несмотря на достаточное активное исследование женского вопроса в Туве в исторической и этнографической плоскостях.

Из исторических работ советского периода следует отметить исследование Н. А. Сердобова «Коминтерн и революционная Тува» (Сердобов, 1985), в котором он, наряду с другими темами, рассматривает вопросы раскрепощения женщин и их участие в «некапиталистическом развитии» Тувы. О влиянии женщин Русской самоуправляющейся трудовой колонии на развитие делегатских собраний среди тувинок писал Ю. Л. Аранчын (Аранчын, 1977). 3. Ю. Доржу изучала социальное положение тувинских женщин и их участие в общественно-политической жизни (Доржу, 1993, 2008, 2011). Положение женщин Тувы в семье и обществе в первой половине XX века стало объектом научного анализа в монографии Г. А. Забелиной (Забелина, 2010). М. В. Монгуш реконструировала и проанализировала образ и статус тувинской женщины в семье и обществе на основе работ русских, зарубежных этнографов и антропологов (Монгуш, 2010). Об особенностях брачно-семейных отношений у тувинцев и их трансформации в советский период писала С. М. Биче-оол (Биче-оол, 2018). Роль женщины-матери в традиционной тувинской семье анализировала 3. В. Анайбан (Анайбан, 2016). Исследования указанных авторов внесли значительный вклад в изучение «женского вопроса» в разные периоды истории Тувы. Вместе с тем вопрос изменения конституционного и гражданско-правового положения женщин в ТНР через призму уголовных, гражданских законов не исследовался, и в такой постановке проблемы специальных работ нет. 
В Туве до распада Цинской империи применялась система законов, разработанная цинскими властями специально для внешних территорий, к которым относились Монголия и территория Тувы. В 1921 г. новое тувинское государство первым делом утвердило Конституцию, определяющую общественное, государственное устройство, основные права и обязанности граждан. Всего в период ТНР было принято шесть Конституций (в 1921, 1924, 1926, 1930, 1936, 1941 гг.) (Конституции Тувы ..., 1999). Тувинское государство принимало законы, которые регулировали новые социальные нормы и утверждали новые инструменты социального контроля через введение специальных норм и санкций. Эти законы определяли, в том числе, место женщин в социальных отношениях. Изучение этой темы является актуальным исследовательским направлением для понимания истоков современных гендерных диспропорций в тувинском обществе.

Целью настоящей статьи является исследование изменения общественно-политического, правового и социального статуса тувинских женщин, их эмансипации через анализ текстов конституций и законов ТНР. Исходя из цели были поставлены следующие исследовательские задачи: провести анализ законов ТНР с точки зрения регулирования правового положения женщин, объяснить генезис и содержание отдельных норм законов, касающихся правового статуса женщин, с учетом социокультурной, политической ситуации в ТНР на разных этапах ее развития, реконструировать и осмыслить социальные условия, в которых принимались те или иные нормы законы ТНР, провести сравнительный анализ норм тувинских законов, имеющих отношение к женщинам, с нормами советского законодательства.

В качестве источниковой базы использованы опубликованные тексты конституций ТНР на русском и тувинском языках ${ }^{1}$, а также уголовные и гражданские законы THР на монгольском, тувинском, русском языках. Это: «Закон о привлечении к судебной ответственности» 1923 г., краткий перевод которого (с монгольского на тувинский язык) хранится в Национальном архиве Республики Тыва (далее - НА РТ) (НА РТ, ф. 93, оп. 1, д. 4; на 21 листе об.), «Уголовное Уложение ТНР» (незаверенная копия) 1930 г., переведенное на русский язык, находится также в фондах указанного архива (НА РТ, ф-п 93, оп. 1, д. 13; на 35 л.). В Научном архиве Тувинского института гуманитарных и прикладных социальноэкономических исследований при Правительстве Республики Тыва (далее - НА ТИГПИ) хранятся в опубликованном виде следующие законы, использованные при написании статьи: «Уголовный кодекс. Особый раздел», на монгольском языке в 1927 г. (Šigükü čaүačan-u bičig. Tusgai anggi); «Закон о браке, семье, опеке над сиротами, недееспособными (душевнобольными) несовершеннолетними и совершеннолетними лицами» (Asssak kadaj polcur polgas өq iștinde kizilernin tugajb, paza eskys polgaş xar cetpeen ijik-pe, xar cetken polza-taa soluu aarıqlьq kizilerni xaragalzap kamgalaar tyrym) на тувинском языке; «Закон о труде THP» 1933 г. на русском языке; «Уголовный закон THP» (TAR kriminel (eruu) tyrymy) 1934 г. на тувинском языке; «Закон о труде ТНР» (Tьba Arat Respubliktьๆ kyş-azыl tyrymy) 1938 г. на тувинском языке; «Уголовный кодекс THР» (TAR kezemce tyrymy) 1941 г. на тувинском языке2.

Кроме указанных источников, в статье использованы документы из Российского государственного архива социально-политической истории (далее - РГАСПИ) (РГАСПИ, ф. 495, оп. 153, д. 1, л. 27-28; ф. 495, оп. 153, д. 37, л. 11).

Большую ценность для данной темы представили документы Тувинской Народно-Революционной партии (далее - ТНРП) и женотдела при Центральном Комитете Тувинской Народно-Революционной партии (далее - ЦК ТНРП), опубликованные на монгольском языке: Tiva arad-un qubis $\gamma a l t u$

\footnotetext{
${ }^{1}$ Конституции Тувы. 1921-1993 гг. Кызыл, 1999; Тьba Arat Respubliktьп Yndezin Xoojluzu (Konstituzu). Кьzьl: Тьbа Kurunenin nom cogaadbr ceri, 1932 (На тув. яз.); Конституция ТНР. Кызыл: Тувинское государственное книжное издательство, 1932; Тьbа Arat Respubliktьп Yndezin Xoojluzu (Konstituzu). Kьzьl: TAR Picce Xural Prezidiumu, 1941 (На тув. яз.); Конституция ТНР. Кызыл: Президиум Малого Хурала, 1941.

2 Šigükü ča kadaj polcur polgas eq istinde kizilernin tugajь, paza eskys polgas xar cetpeen ijik-pe, xar cetken polza-taa soluu aarıqlьq kizilerni xaragalzap kamgalaar tyrym [Закон о браке, семье, опеке над сиротами, недееспособными (душевнобольными) несовершеннолетними и совершеннолетними лицами]. Kьzьl: Oficial cogaal, 1932 (Ha тув. яз.); Закон о труде. Кызыл: Гостипография, 1933; TAR kriminel (eruu) tyrymy [Уголовный закон THP]. Кьzы: Ystykky syygyden yndyrgen. Кызыл: Издание Верховного суда ТНР. 1934 (На тув. яз.); Тьba Arat Respubliktьๆ kyşаzыl tyrymy [Закон о труде THP]. Кьzьl: TAR Picce Xural Prezidiymynyп ceri. Кызыл: Президиум Малого Хурала, 1939 (На тув. яз.); TAR kezemce tyrymy [Уголовный кодекс]. Кьzыl хoraj: Ystykky syygyden yndyrgen, 1942 (На тув. я3.).
} 
nam-un naymaduyar yeke hural-un tobči togtayal [Постановление VIII съезда ТНРП]; Tiva aradun qubisyaltu nam-un mörün kötülbüri [Программа ТНРП 1929 г.] 1929 г.; 1930 duүar on 11 sara-

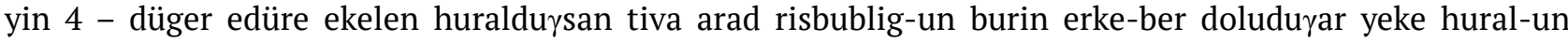
tobči toqtayal [Постановление VII Великого Хурала THP, 4 ноября 1930 г.]; Bükü Tiva emegteiyčüd-

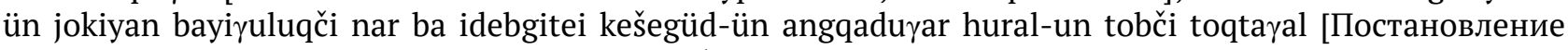
первого всетувинского организационного собрания женщин и активисток] ${ }^{1}$.

\section{Общественно-политический статус тувинских женщин до 1921 года}

Оценки положения тувинских женщин до 1921 г. и после провозглашения ТНР, нашедшие отражение в документах и литературе периода ТНР, были выстроены в рамках достаточно однобокой идеологической конструкции, которую использовали в политических целях. Во всех материалах указанного периода - в партийных документах, агитационной литературе, публикациях в партийных журналах - присутствовали оценки, которые можно изложить в нескольких тезисах:

- тувинские женщины до 1921 г. были бесправны во всех отношениях, приравнивались к домашним животным или вещам (имуществу), которые можно продать;

- тувинские женщины жили в темноте и невежестве, их не воспринимали как людей, воспринимали как грязные существа;

- тувинские женщины были бесправны, находились под многократным угнетением и эксплуатацией иностранных империалистов, местных феодалов и лам;

- лишь после 1921 года положение женщин улучшилось и решающую роль в этом сыграло принятие тувинской властью новой политики советского государства.

Но зададимся вопросом о том, так ли бесправны были ли тувинские женщины, как указывалось в работах, к примеру, Г. А. Забелиной (см.: Забелина, 1977: 92)? Начиная с древних времен в кочевых обществах главным в семье был мужчина, но роль женщин в хозяйстве была высокой. В Монгольской империи (XIII-XIV вв.), в состав которого входила и территория Тувы, по наблюдениям Плано Карпини는, в хозяйственной деятельности кочевников доля участия женщин значительно превышала вклад мужчин (Кляшторный, 1985: 164). Известный российский монголист Б. Я. Владимирцов также указывал на то, что женщины в Монголии того времени, играя значительную роль в хозяйстве, участвовали и в общественной жизни (Владимирцов, 1934: 56).

После распада монгольской империи тувинцы находились в составе государства Алтын-ханов (XVII-XVIII в.). Главную роль в тувинской семье продолжал играть мужчина. Вместе с тем есть свидетельства об участии женщин из знати Алтын-ханов в политических, дипломатических и управленческих вопросах (Почекаев, 2018: 25). Однако, это касалось только высшей аристократии, и вряд ли относилось к простым женщинам.

В эпоху маньжурской империи Цин в Туве (середина XVIII - начало XX в.) сохраняется моногамная семья с главенствующей ролью мужчины. Как утверждал Ф. Кон, посетивший Туву в 1902-1903 гг., несмотря на свое подчиненное положение, женщина пользовалась авторитетом и принимала участие в решении семейных вопросов. Он указывал на существование патриархальных больших семей, состоящих из представителей трех поколений и ведущих общее хозяйство под руководством старшего мужчины, а в случае смерти - его жены (Кон, 1934: 251).

В период империи Цин правоотношения в Монголии и Туве регулировало Уложение Китайской Палаты Внешних Сношений, в которых были отражены также нормы семейного права. В уголовной

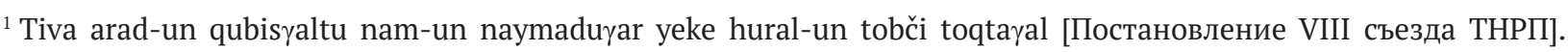
Кызыл, 1929. (На монг. яз.); Tiva arad-un qubisүaltu nam-un mörün kötülbüri [Программа ТНРП 1929 г.]. Кызыл, 1929. (На монг. яз.); 1930 durar on 11 sara-yin 4 - düger edüre ekelen huraldursan Tiva arad risbublig-un bürin erkeber dolodurar yeke hural -un tobči togtaral [Постановление VII Великого Хурала ТНР, 4 ноября 1930 г.].

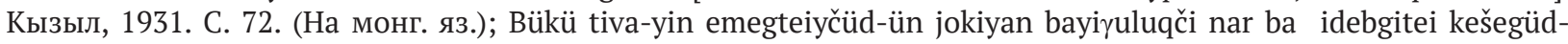
ün angqaduyar hural-un tobči toqtayal [Постановление первого всетувинского организационного собрания женщин и активисток]. Кызыл, 1930 (На монг. яз.); Резолюции Х съезда ТНРП. Кызыл, 1937.

${ }^{2}$ Плано Карпини (Иоанн де Плано Карпини) - итальянец по происхождению, по поручению римского папы Иннокентия IV посетил Монгольскую империю в 1245-1247 гг. с дипломатическими и миссионерскими задачами. По итогам своего путешествия написал книгу «История монголов, именуемых татарами». См.: Путешествия в восточные ..., 1957: 6-7. 
части Уложения, например, содержались нормы, согласно которым за умышленное убийство жены вне зависимости, чиновник он или простолюдин, виновник приговаривался к удавлению. К этой же мере наказания подвергались те, чье жестокое отношение к женам приведет к их смерти ${ }^{1}$ Цинские законы установили правила и нормы поведения между полами. Они показывают, прежде всего, ранговое, сословное, имущественное неравенство через систему дифференцированного наказания за правонарушения в сфере семейно-брачных отношений, нежели неравенство между мужчинами и женщинами. В тексте Уложения нет отсылок к равным правам или неравноправию между мужчинами и женщинами, но есть разные меры наказания за одни и те же виды преступлений аристократу или простолюдину.

В бытовой жизни на тувинских женщинах многое держалось. Ярким примером хозяйственной самостоятельности женщин у тувинцев является практика перекочевки, связанная с сезоном охоты у тувинцев-тоджинцев. Муж, уходя на охоту, указывал жене место, куда он явится во время промысла, и на это место она должна была перекочевать с детьми, со всем скарбом. Все заботы по перекочеванию лежали на ней: она вьючила лошадей, перегоняла скот (Кон, 1934: 137).

В выживании семьи, рода, народа в кочевом обществе в условиях сурового климата, войн, перекочевок, вызванным типом хозяйствования, основную роль играл труд женщин. Значимая роль женщины в хозяйственных вопросах семьи, возможно, предопределяла достаточно высокий уровень свободы и статуса женщин.

На основе работ русских путешественников, изучавших Туву в конце XIX - начале XX в. и оставивших ценные этнографические наблюдения, составлялась картина свободного, независимого нрава тувинской женщины, ее самодостаточности и искусности в хозяйстве (Монгуш, 2010: 140).

Однако были сферы, закрытые для женщин. Во-первых, женщины не имели доступа к образованию и постижению буддийской философии: монастырское образование было исключительно мужским, женских монастырей не было. В этом проявилась в том числе ограничительная политика Цинских властей. В общих постановлениях Уложения Китайской палаты внешних сношений касательно ламского духовенства был установлен запрет «всем монгольским девицам и женщинам поступать в монахини по собственному произволению. Тех, которые учинят вопреки сему положению, разстригать и обращать в прежнее состояние» ${ }^{2}$. Кроме того, строго запрещалось женскому полу ходить в монастыри, в которых живут ламы.

Женщины в Цинский период не имели доступа к государственным делам и управлению - тувинские чиновники того времени были исключительно мужчинами. Равные права с мужчинами в соответствии с Конституцией и законами тувинские женщины получили только после провозглашения Тувинской Народной Республики.

Представляется, что до 1921 г. бесправие тувинских женщин действительно имело место в таких сферах, как политика, управление, получение образования. Однако, следует помнить о том, что таких возможностей не имело большинство аратов-мужчин - в хозяйственной жизни семьи статус тувинских женщин не был таким приниженным, как описывалось в идеологизированных партийных документах и агитационной литературе ТНР. Как выше указано, в цинский период письменные законы империи, основанные на обычном праве монголов, содержали нормы, предусматривающие виды наказания за причинение физического вреда и убийства жен, за нарушения установленных правил семейнобрачных отношений.

\section{Права женщин в Тувинской Народной Республике}

Во втором параграфе первой Конституции Республики Танну-Тува Улус, принятой по итогам Всетувинского Учредительного Хурала в 1921 г., было провозглашено, что «все граждане Танну-Тува Улус равны перед законом, издаваемым с согласия всего народа» (Конституции Тувы ... , 1999: 25). Поскольку под понятием «все граждане Танну-Тува Улус» подразумевались все жители Тувы, эта норма подчеркивала равенство перед законом мужчин и женщин, а также одинаковую ответственность. Но, несмотря на это, в первые годы ТНР тувинские женщины воспользоваться всеми правами в

${ }^{1}$ Уложение Китайской Палаты ВнЂшнихъ Сношеній : пер. с маньчж. С. Липовцовъ. Санктпетербургъ, 1828. Т. II.

Ч. III. C. 77.

${ }^{2}$ Уложение Китайской Палаты ВнЂшнихъ Сношеній : пер. с маньчж. С. Липовцовъ. Санктпетербургъ, 1828. Т. II.

Ч. IV, Глава IX. С. 225. 
реальной жизни не могли в силу неграмотности, незнания своих прав. Также в обществе отсутствовала соответствующая политическая культура, были достаточно сильны предрассудки относительно роли и места женщины в обществе.

Политическая социализация тувинских женщин, как и везде, была очень непростым процессом. Не случайно «женский вопрос» становится одним из важнейших тем в политической повестке ТНР.

О равноправии мужчин и женщин более четко было сказано в «Основных законах ведения политической работы народного правительства Тувинской Народной Республики» 1923 г.: «... отныне, несмотря на пол, возраст, все люди равноправны. Право избирать и быть избранным имеют все граждане независимо от пола в возрасте 20 лет и выше» (Конституции Тувы ..., 1999: 30). Это было первое в истории тувинского общества наделение женщин политическими правами, формальное закрепление принципа и нормы, обеспечивающих возможность для участия женщин в общественнополитической жизни, а право быть избранным - в управлении государством.

Данная норма также в последующем воспроизведена в пункте 17 Конституции 1924 г. (там же: 37).

В Конституции ТНР 1926 г. было признано равноправие граждан независимо от их национальности, религии и пола. Избирательными правами в ТНР по Конституции 1926 г. наделялись граждане обоего пола (мужчины и женщины), достигшие ко дню выборов 18-летнего возраста (там же: 45). Данная норма была сохранена в Основном Законе (Конституции) Тувинской Аратской Республики ${ }^{1}$ (далее ТАР), утвержденной в 1930 г. ${ }^{2}$

Тувинские женщины в 1930 г. получили права на свободное политическое волеизъявление через публичные мероприятия. В первом разделе конституции ТАР 1930 г. были признаны права граждан на свободное проведение собраний, митингов, демонстраций и республика брала на себя обязанности для предоставления под эти цели соответствующих зданий и сооружений³

В Конституции Тувинской Народной Республики 1941 г. впервые осуществлена детализация прав женщин. В статье 77 было прописано, что:

«женщине в ТНР предоставляются равные с мужчиной права во всех областях государственной, хозяйственной, культурной и общественно-политической жизни страны. Возможность осуществления этих прав обеспечивается предоставлением женщине равных с мужчиной условий и оплаты труда, отдыха, социального страхования, образования, а также государственной охраной интересов матери и ребенка, предоставлением женщине при беременности отпуска с сохранением за работающими по найму содержания. Какое бы то ни было прямое или косвенное нарушение равноправия женщины, воспрепятствование участию их в государственной, хозяйственной, культурной, и общественно-политической жизни, воспрепятствование поступлению женщин в школы, а также насильственная выдача замуж несовершеннолетних и вступление с ними в брак караются законом»4.

Безусловно, на конституционный процесс в Туве в целом и на содержание закрепляемых норм влияли, прежде всего, советские конституции. Следует отметить, что в исследовательской литературе была позиция, согласно которой советская модель конституций заимствовалась Тувой через монгольский опыт. На основе сравнительного анализа текстов монгольской и тувинской конституций С. В. Шостакович, к примеру, считал, что многие институты, свойственные советским конституциям, были рецепированы ${ }^{5}$ Танну-Тувой не непосредственно, а через монгольскую Конституцию (Шостакович, 2007: 205). При этом С. В. Шостакович не указывал на то, что Монголия приняла свою первую конституцию в 1924 г. после кончины Богдо-Гегена VIII, в то время как в ТНР первая конституция была принята в 1921 г. Скорее всего, он сравнивал первую монгольскую конституцию 1924 г. с третьей тувинской конституцией 1926 г. Действительно, был такой факт, когда в 1926 г. ЦК ТНРП при участии уполномоченного Исполнительного комитета Коммунистического Интернационала (да-

\footnotetext{
${ }^{1}$ Следует указать на то, что в названиях и текстах конституций разных лет на русском языке указаны разные названия тувинского государства: в конституции 1921 г. - Республика Танну-Тува Улус; 1924 и 1926 гг. Тувинская Народная Республика; 1930 г. - Тувинская Аратская Республика; 1936 и 1941 гг. - Тувинская Народная Республика (см.: Конституции Тувы ..., 1999). На тувинском языке, за исключением первой Конституции 1921 г. (Танну-Тува Улус), название одно и тоже - «Тыва Арат Республика».

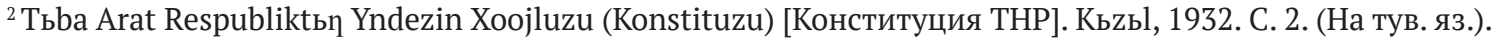

${ }^{3}$ Там же. С. 4.

${ }^{4}$ Tьba Arat Respubliktьฤ Yndezin Xoojluzu (Konstituzu) [Конституция THP]. Кьzьl: TAR Picce Xural Prezidiumu. 1941. С. 30. (На тув. яз.).

${ }^{5}$ Рецепция - принятие, заимствование правовой системы, правовых норм других стран.
} 
лее - ИККИ) С. А. Нацова рассматривал проект Конституции ТНР, подготовленный на основе Конституции Монголии (принятой I Великим Хуралданом Монголии). Конституция Монголии была разработана преимущественно Т. Р. Рыскуловым, уполномоченным ИККИ в этой стране. Указанный проект Конституции ТНР, представленный членами законодательной комиссии Малого Хурала ТНР Нимажапом и Шыырапом в ЦК ТНРП, был забракован и передан на доработку специальной комиссии, в которую вошли Содном (генеральный секретарь ТНРП), Дондук (председатель Совета министров ТНР) и Хемчик-оол (заведующий агитацией и пропагандой ЦК ТНРП) ${ }^{1}$. Можно предположить, что это не было случайностью.

Несмотря на декларируемое сотрудничество, близость Монголии и ТНР, Коминтерн все же следил за тем, чтобы не допускать реального сближения двух стран по ряду политических причин. «Монголофилы» - именно так с негативным оттенком называли часть тувинского руководства, которая шаг за шагом была отодвинута от власти и руководства партии. Нимажапа и Шыырапа, представивших монгольскую конституцию, уполномоченный ИККИ С. Нацов в письме Чичерину и Петрову называл «столпами монголофильства». Они были отстранены от дальнейшей работы над конституцией. Тот факт, что в 1925 г., к примеру, под контролем уполномоченного ИККИ в ТНР А. М. Амур-Санана не допустили переизбрания в ЦК ТНРП Шагдыра и Нарымдаха, которые ранее входили в состав высшего руководства партии как «монголофилов» (РГАСПИ, ф. 495, оп. 153, д. 3, л. 83), говорит о целенаправленной политике ИККИ против промонгольских настроений среди партийных и государственных деятелей ТНР.

В такой ситуации прямой перенос монгольских законов в ТНР, и наличие идентичных конституций у двух граничащих друг с другом стран с общим историческим прошлым и не до конца разорванными связями между бывшими элитами, как мы полагаем, было политически неприемлемым. По этой причине, по нашему мнению, проект конституции ТНР 1926 г., основанной на монгольской конституции, был переработан.

Закрепление равных прав мужчин и женщин с точки зрения равенства перед законом в конституции THP 1921 г., закрепление равных избирательных прав граждан обоего пола в конституции 1923 г., что позволяло женщинам полноценно участвовать в политической жизни - это были решения, которые имели революционное значение для патриархального тувинского общества. Даже в свете современных реалий уже XXI века для некоторых стран вопрос предоставления политических прав женщинам остается актуальным. С учетом того, что в тот период Тува стала независимым государством, это решение ставит ее в ряд с теми немногими государствами, которые к тому времени признали равные политические права мужчин и женщин. Если обратимся к фактам политической истории европейских и азиатских стран, Советская Россия была седьмым государством, которое после Февральской революции 1917 г. признала равные права мужчин и женщин после Новой Зеландии (1893), Австралии (1902), Финляндии (1906) Норвегии (1913), Дании и Исландии (1915), предоставившей женщинам политические права, а именно, избирательные права (Темкина, 2004: 44) Великобритания, например, такие права женщинам предоставила в 1928 г., Франция, Венгрия, Италия, Япония - уже после Второй мировой войны - в 1945 г. (там же: 44), Китай - в 1954 г. (Антонова, 2008: 53). Как мы видим в докладе $\mathrm{OOH}$ о политическом участии женщин арабского региона, в таких странах, как Бахрейн (2002), Кувейт (2005), ОАЭ (2006), Саудовская Аравия (2011), с учетом их социокультурных особенностей женщины получили избирательные права только в XXI веке 2 .

Таким образом, на политической карте мира Тувинская Народная Республика была в числе первых государств, признавших равные права женщин и мужчин, и наделивших женщин избирательными правами. Однако, к сожалению, этот факт обходят вниманием исследователи темы политических прав женщин в XX в. (см., напр.: Темкина, 2004: 44; Мурзова, Жиляева, 2018: 89). В научной литературе о политических правах женщин ТНР упоминается лишь как первое государство в мировой истории, которое в результате выборов возглавила женщина - в 1940 г. Хертек Анчимаа-Тока стала председателем Малого Хурала ТНР (там же: 90). Конституционного закрепления общественно-политических прав женщин было недостаточно для внедрения новой модели социальных отношений в Туве.

${ }^{1}$ Письмо С. А. Нацова Чичерину и Петрову от 13.11.1926 (РГАСПИ, ф. 495, оп. 153, д. 5, л. 114).

${ }^{2}$ Women's Political Representation in the Arab Region. Beirut: United Nations, 2017. P. 9. 


\section{Женцины в уголовных законах ТНР}

В период ТНР активно разрабатывались уголовные и гражданские законы, в которые не раз вносились изменения под влиянием как внутренних, так и внешних факторов. При этом надо отметить тот факт, что отдельных законов, регулировавших «женский вопрос», не было. Одним из первых тувинских законов явился «Закон о привлечении к судебной ответственности», состоящий из 83 пунктов, принятый в сентябре 1923 г. Закон разрабатывался специально созданной комиссией. Документ с указанием состава разработчиков, в том числе советников из СССР, хранится в Национальном архиве Республики Тыва (НА РТ, ф. 93, оп. 1, д. 4, л. 9, п. 59).

В послецинский период это был первый собственно тувинский закон, который определил перечень уголовно наказуемых деяний, в том числе в отношении женщин. Закон определил меру уголовной ответственности за насильственные половые действия в отношении несовершеннолетних девушек, предусматривая лишение свободы на 3 года, а также за насилие в отношении совершеннолетних девушек, женщин - лишение свободы на 1 год (НА РТ, ф. 93, оп. 1, д. 4, л. 9, п. 59).

Кроме того, данным законом каралась супружеская неверность: «Если женатый мужчина или замужняя женщина будут вступать в отношения с другой женщиной или другим мужчиной, этого мужчину и женщину каждого по отдельности заключить тюрьму в течение месячного срока» (там же: л. 17, п. 81).

При разводе супругов преимущественно защищались права оставленной стороны: «При разводе, если кто-то из супругов оставляет другого, то он свою часть имущества передает детям или оставленной супруге или супругу, совместно нажитое имущество остается полностью детям и оставленной стороне» (там же: л. 18, п. 82).

Супружеская неверность порицалась еще в средние века. Свидетельством тому служат нормы обычного права кочевников, послужившие основой для средневековых письменных законов Монголии, а также для цинских законов, а именно, для Уложения Китайской Палаты Внешних Сношений. Например, «Их цааз» регулировал случаи прелюбодеяния со стороны замужней женщины, и пункт 107 - при применении сексуального насилия со стороны мужчины. «Если замужняя женщина сойдется с посторонним мужчиной по обоюдному согласию и взаимной любви, то с женщины взять четыре головы скота, а с мужчины - пять» ${ }^{2}$. В уголовной части Уложения китайской Палаты Внешних Сношений, например, говорилось: если «простолюдин учинял любодеяние с женщиной равного звания по взаимному согласию, то дать преступнику плетью 100 ударов, продержать прежде 1 месяц в шейной колодке, равному наказанию подвергать и преступницу, только вместо шейной колодки взять откуп» ${ }^{2}$ В случае развода, согласно разделу о браках Уложения, разводящийся мужчина «обязан был возвратить женщине все те вещи, которые она принесла с собой в приданое, если только оныя находятся в наличности. Если же часть из оных поступила в употребление, то разведенная не имеет права требовать с него оных» ${ }^{3}$.

В 1927 г. был принят особый раздел Уголовного закона ТНР4. Во-первых, половая неприкосновенность девушек до 15 лет защищается законом. Первый пункт раздела о преступлениях, связанных с развратом и распутством, за связи с девушками младше указанного возраста устанавливал наказание в виде заключения под стражу от 1 месяца до 1 года или штраф от 50 до 600 тугриков 5

В последующей редакции, а именно в Уголовном Уложении ТНР 1930 г., этот возраст будет повышен до 18 лет, а наказание ужесточено. Эта регламентация, как мы считаем, могла коснуться добрачных отношений молодежи, в ходе игр ойтулааш. С. И. Вайнштейн, например, считал, что ойтулааш у тувинцев означал добрачные игры молодежи с традициями половой свободы (Вайнштейн, 1964: 123-124). Есть противоположное мнение С. М. Биче-оол, которая считает, что по отдельным случаям «ухаживаний» и интимных связей нельзя расценивать ойтулааш как проявление половой свободы (Биче-оол, 2018: 30). Как бы то ни было, половая неприкосновенность девушек до совершеннолетия стала защищаться законом.

\footnotetext{
${ }^{1}$ Их Цааз («Великое Уложение»). Памятник монгольского феодального права XVII : пер. С. Д. Дылыкова. М. : Восточная литература, 1981. С. 23.

${ }^{2}$ Уложение Китайской Палаты Внбшнихъ Сношеній : пер. С. Липовцовъ. Санктпетербургъ, 1828. Т. II. Ч. III. C. 112.

${ }^{3}$ Уложение Китайской Палаты ВнЂшнихъ Сношеній : пер. С. ЛиповцовЪ. Санктпетербургъ, 1828. Т. І. С. 329.

4 Šigükü čayačan-u bičig. Tusgai anggi. 1927 [Уголовный кодекс. Особый раздел. 1927]. Кызыл, 1927 г. (На монг. яз.).

${ }^{5}$ Там же. С. 47.
} 
Во-вторых, было более четко, чем в Законе о привлечении к судебной ответственности 1923 г., прописано уголовное наказание за насильственные половые сношения с девушками. В соответствии со вторым пунктом вышеуказанного раздела о разврате и распутстве данного закона применение сексуального насилия в отношении девушек старше 16 лет влекло за собой наказание от 3 месяцев до 3 лет заключения или штраф от 150 до 1200 тугриков. Если насильственное преступление совершено группой лиц, наказание было более суровым - от 3 лет до 5 лет заключения. В случае насилия в отношении девушек младше 15 лет виновника приговаривали к заключению от 1 года до 5 лет, если в группе в отношении девушек указанного возраста - от 5 лет до 8 лет заключения.

B-третьих, Уголовный закон ТНР 1927 г. был направлен на запрет проституции и вовлечения в эту деятельность тувинских женщин. Так, четвертый пункт вышеуказанного раздела о разврате и распутстве данного закона гласил: «Если кто-то с желанием извлечения выгоды для себя отдаст на пользование женщину или девушку другому человеку, назначалось наказание в виде тюремного заключения от 1 до 3 месяцев, или штраф от 150 тугриков до 600 тугриков» ${ }^{1}$. В соответствии со следующим пунктом, «если для извлечения прибыли кто-то будет привлекать женщин и девушек к проституции, поставив отдельную юрту (жилище), виновник должен был отбыть наказание в виде заключения сроком от 6 месяцев до 2 лет»². Частичной и полной конфискации подлежало использовавшееся имущество ${ }^{3}$

Рассматривая этот пункт уголовного закона, сложно прямо ответить на вопрос, насколько была проституция как социальное явление распространена в дореволюционной Туве и в первые годы ТНР. Если обратиться к материалам этнографических экспедиций в Туву, у многих, в том числе в отчетах Ф. Кона, Н. Катанова, мы находим оценки степени свободы добрачных отношений у тувинцев.

«Одной из характернейших особенностей сойотов было их отношение к женщине. Во многих сойотских поселках, даже у ойнаров, самых культурных сойотов, мне приходилось видеть юрты, в которых жили взрослые девушки, каждая в отдельной юрте. Это делалось для того, чтобы девушка могла свободно располагать собой и без стеснения принимать своего возлюбленного несмотря на то, что ни девушка, ни парень не собираются скрепить эти связи брачными узами. Только после того, как невеста переехала из своей юрты в улус жениха, связь с другим считается предосудительной» (Кон, 1934: 128).

Но при этом сам Кон указывает на то, что тувинцы презирали девушек, имевших связь с мужчинами в расчете на материальное вознаграждение, женщин, которые вели разгульный образ жизни. Следует отметить, что с учетом повсеместной бедности простых тувинцев, которые были связаны круговой порукой, в том числе по долгам китайским ростовщическим купцам, тяжелого бремени дани албату цинским властям, сложно представить, что семьи могли позволить себе содержать отдельные юрты для дочерей, не вступивших в брачные отношения. Также связи с мужчинами за оплату как род деятельности с учетом общественного порицания вряд ли могли быть распространенными среди тувинских женщин. С этой точки зрения, можно предположить, что описанная практика могла носить спорадический характер. Тем не менее, привлечение женщин к такого рода деятельности уголовным законом ТНР было отнесено противоправному деянию.

Необходимо указать на то, что уголовный закон ТНР практически дословно повторил статьи 170 , 171 уголовного кодекса РСФСР 1922 г. о проституций. Поскольку шла рецепция советской системы права, то зачастую нормы переносились автоматически.

В-четвертых, данный закон ТНР включил в разряд уголовных преступлений кровосмесительные половые связи: «Если кто-то вступит в половые отношения с родственниками в рамках четырех поколений (по возрасту и старше, и младше) по отдельности, то будет помещен в тюрьму со сроком от 3 месяцев до 1 года или будет оштрафован от 150 тугриков до 600 тугриков»5.

Генезис данной нормы, а также запрета на кровосмесительные браки в «Законе о браке, семье и опеке над сиротами, недееспособными несовершеннолетними и совершеннолетними» ${ }^{6}$, принятого в 1930 г.,

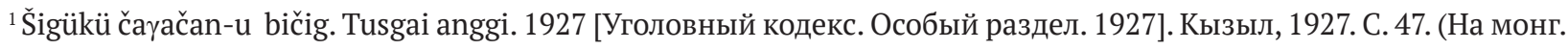
яз.).

${ }^{2}$ Там же.

${ }^{3}$ Там же. С. 48.

${ }^{4}$ Уголовный кодекс 1922 г. [Электронный ресурс] // Музей истории российских реформ имени А. П. Столыпина. URL: https://музейреформ.pф/node/13810 (дата обращения: 25.11.2020).

${ }_{5}^{5}$ Šigükü čayačan-u bičig. Tusgai anggi. 1927 [Уголовный кодекс. Особый раздел. 1927]. Кызыл, 1927. С. 48. (На монг. яз.).

${ }^{6}$ Asssak kadaj polcur polgas eq iştinde kizilernin tugajb, paza eskys polgas xar cetpeen ijik-pe, xar cetken polza-taa 
по нашему мнению, имеет двоякий характер. С одной стороны, воспроизводство тувинских родов основывалось на древней традиции экзогамных браков, что было прямым императивом в брачных отношениях (см.: Кон, 1934: 133; Потапов, 1969: 229; Биче-оол, 2018: 27). Согласно Е. Д. Прокофьевой, у тувинцев по материнской и отцовской линиям четыре поколения женщин составляли группу элеге, то есть ту группу, из которой нельзя было брать жен. Возможность жениться наступала только с пятого поколения по материнской и отцовской линии - кая (Прокофьева, 1955: 5). С этой точки зрения запрет и наказание за кровосмесительные половые отношения и браки в тексте закона могли быть сформулированы под влиянием традиционных моральных устоев и исторически сложившихся норм брачного поведения тувинцев. С другой стороны, нельзя отрицать влияния советских законов. В декабре 1917 г. был принят Декрет ВЦИК и СНК РСФСР «О гражданском браке, о детях и о ведении книг актов гражданского состояния», согласно которому не допускались, например, браки между родственниками по прямой линии (между некоторым лицом и его детьми, внуками по прямой линии), полнородными и неполнородными братьями и сестрами (родственниками по боковой линии) ${ }^{1}$.

В-пятых, Уголовный закон ТНР 1927 г. установил защиту добровольности и осознанности выбора женщины как в половых отношениях с мужчинами, так и при заключении брака. Так, например, в случае, «если кто-то воспользовался женщиной, находящейся в бессознательном состоянии из-за опьянения» ${ }^{2}$ ему полагалось наказание в виде заключения от трех месяцев до 1 года или штраф от 150 до 600 тугриков ${ }^{3}$. Аналогичной мере наказания подлежал и тот, кто «путем обмана, силы, устрашения женился» 4 .

В-шестых, Уголовный закон ТНР 1927 г. был ориентирован также на борьбу с венерическими заболеваниями. Тот, кто, зная, что болен сифилисом и гонореей, вступал в сношения с другими, должен был уплатить штраф от 50 до 600 тугриков 5 . Это была достаточно серьезная социальная проблема. Первая комплексная научная экспедиция АН СССР в Туву, которая занималась сбором рекогносцировочного материала по медико-санитарным проблемам, состоялась в 1926 г. По данным А. П. Преображенского, врача, входившего в состав экспедиции, сифилис был распространен во всех районах республики концентрированными очагами. Данные первой медико-санитарной экспедиции Наркомздрава РСФСР в Туве в 1927-1928 гг. свидетельствовали о том, что вопрос о сифилисе стоял достаточно остро (Башкуев, 2018b: 53, 57). Инфекционные болезни, заболевания, передающиеся половым путем, были социальной проблемой в начале XX века не только для тувинцев, но и для других кочевых народов. Это объяснялось особенностями кочевого быта, отсутствием санитарно-гигиенических знаний, больниц, врачей и медицинского обслуживания. По данным Б. Б. Цыретаровой, специальное медицинское обследование бурятского населения в 1923 г. в Бурят-Монгольской АССР показало, что сифилисом было заражено 60,7\% населения, гонореей - 90\% (Цыретарова, 2016: 30). Советская медико-санитарная экспедиция, которая работала в Монголии в 1927 г., также выявила достаточно высокий уровень распространения венерических заболеваний у населения (Башкуев, 2018а: 19).

Тувинские законодатели использовали и такой вид регулирования, как штрафы за половые связи неизлеченных венерических больных. В условиях малочисленности тувинцев, а также отсутствия полноценной сети медицинских учреждений и недостатка врачей такая мера была более действенной. Таким образом, включение в Уголовный закон ответственности за распространение социально опасных венерических заболеваний было одним из проявлений государственной политики в вопросах здоровья и сохранения тувинского народа в целом, а для тувинской женщины - фактором оздоровления и повышения фертильности и репродуктивных функций. Контент-анализ многих партийных доку-

soluu aarьqlьq kizilerni xaragalzap kamgalaar tyrym [Закон о браке, семье, опеке над сиротами, недееспособными (душевнобольными) несовершеннолетними и совершеннолетними лицами]. Кьzьl: Oficial cogaal, 1932. (На тув. яз.).

${ }^{1}$ Декрет ВЦИК, СНК РСФСР от 18.12.1917 О гражданскомъ браке, о детяхъ и о веденіи книгъ актовъ состоянія [Электронный ресурс] // Викитека. URL: https://ru.wikisource.org/wiki/Декрет_ВЦИК,_СНК_РСФСР_ от_18.12.1917_о_гражданскомъ_браке,_о_детяхъ_и_о_веденіи_книгъ_актовъ_состоянія (дата обращения: 25.11.2020).

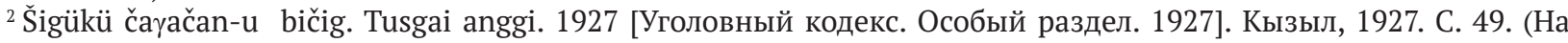
монгольском языке).

${ }^{3}$ Там же.

${ }^{4}$ Там же.

${ }^{5}$ Там же. С. 50. 
ментов показывает понимание руководителями проблемы и необходимости ее решения. Это звучало на съездах ТНРП. Напр., выступление С. К. Тока по вопросам образования и культуры на VIII съезде ТНРП в 1929 г. ${ }^{1}$, об этом говорилось в программе ТНРП 1929 г. ${ }^{2}$, в докладе К. Донгака об организации просвещения на VII Великом Хурале ТНP в 1930 г. ${ }^{3}$ План работы с женщинами, утвержденный первым организационным всетувинском собранием женщин 1930 г., содержал отдельный пункт по борьбе с распространением венерических заболеваний, включая борьбу против промискуитета (беспорядочной половой жизни) и антисанитарии ${ }^{4}$ В 1936 г. на Х съезде ТНРП эти социальные болезни были названы «бичем, тормозящим рост населения» ${ }^{5}$.

Следует добавить, что тувинские законотворцы воспроизвели статью 150 Уголовного кодекса РСФСР 1926 г., в соответствии с которой «заражение другого лица венерической болезнью лицом, знавшим о наличии у него этой болезни карается лишением свободы со сроком до трех лет» ${ }^{6}$ При этом, как и во многих заимствованиях, меры наказания за одни и те же преступления в тувинском законе были менее строгими, чем в советских уголовных кодексах.

С момента принятия уголовного закона 1927 г. прошло всего три года, как закон в 1930 г. получил новую редакцию 7 . За этот короткий период в ТНР произошли существенные изменения политического контекста: ядром программы политических действий ТНРП становится некапиталистический путь развития, в результате борьбы за власть, идеологию, под влиянием теории классовой борьбы произошли изменения в составе политического истеблишмента страны, прежнее руководство было обвинено в правом уклоне, началась борьба с бывшими феодалами, ламами, конфискация их имущества и лишение избирательных прав ${ }^{8}$. Как указывалось в постановлении VII Великого Хурала ТНР, состоявшегося в ноябре 1930 г., «ранее принятые законы не соответствуют развитию некапиталистического общественного порядка, в этой связи правительство активно работало по обновлению законов: обновлены Конституция, уголовный закон, приняты закон о семье, закон о землепользовании, закон о таможне. Все они направлены на защиту интересов бедных и на ограничение прав противоборствующего класса»9 .

Новый закон 1930 г. под названием «Уголовное уложение ТНР» в родах и видах наказания включает поражение гражданских прав в виде лишения через суд родительских прав (НА РТ, ф. 93, оп. 1, д. 13, л. 1, п. 12).

На повышение родительской ответственности была направлена норма, согласно которой за оставление родителями малолетних детей без всякой поддержки лишали свободы до 6 месяцев (там же: л. 22, п. 180). В уголовном законе 1927 г. был раздел об ответственности за оставление пожилых людей и детей в опасном положении, который предусматривал штрафы, если кто-либо не сообщал в соответствующие органы об опасном положении, в котором находятся лица из указанной категории. Введение практики лишения родительских прав свидетельствовало о том, что во внутренних, семейных вопросах воспитания детей появился внешний регулятор в лице государства, которое могло женщин-матерей и мужчин-отцов лишить прав на воспитание своих детей. Такая норма была принята в 1927 г., по нашему мнению, под влиянием статей 46, 47 об условиях лишения родительских прав Кодекса законов о браке, семье и опеке РСФСР 1926 г. ${ }^{10}$ Ни этнографических, ни исторических данных

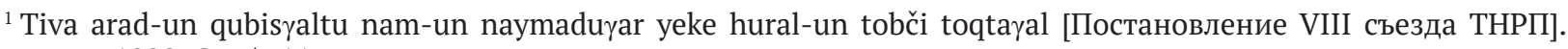
Кызыл, 1929. С. 35-44. (На монг. яз.).

${ }^{2}$ Tiva arad-un qubis $\gamma a l t u$ nam-un mörün kötülbüri [Программа ТНРП 1929 г.]. Кызыл, 1929. С. 28-29. (На монг. яз.). ${ }^{3} 1930$ durar on 11 sara-yin 4 - düger edüre ekelen huraldursan Tiva arad risbublig-un bürin erkeber dolodurar yeke hural -un tobči togtaral [Постановление VII Великого Хурала ТНР, 4 ноября 1930 г.]. Кызыл, 1931. С. 72. (На монг. яз.).

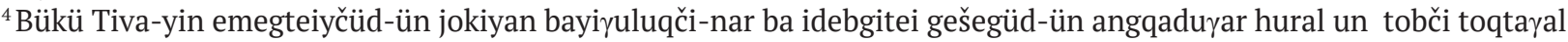
[Постановление первого всетувинского организационного собрания женщин и активисток]. Кызыл, 1930. С. 14. (На монг. яз.).

${ }^{5}$ Резолюции Х съезда ТНРП (1-11 ноября 1936 г.). Кызыл, 1937. С. 12.

${ }^{6}$ Уголовный кодекс 1922 г. [Электронный ресурс] // Музей истории российских реформ имени А. П. Столыпина. URL: https://музейреформ.pф/node/13810 (дата обращения: 25.11.2020).

${ }^{7}$ Уголовное Уложение ТНР (незаверенная копия) 1930 г. (НА РТ, ф. 93, оп. 1, д. 13).

${ }^{8}$ РГАСПИ, ф. 495, оп. 153, д. 50; ф. 495, оп. 153, д. 61. См. также: История Тувы, 2007: 183-184.

${ }^{9} 1930$ durar on 11 sara-yin 4 - düger ... С. 72 .

${ }^{10}$ Постановление от 19 ноября 1926 года «О введении в действие Кодекса законов о браке, семье и опеке» [Электронный ресурс] // Библиотека нормативно-правовых актов Союза Советских Социалистических Республик. URL: http://www.libussr.ru/doc_ussr/ussr_3124.htm (дата обращения 24.11.2020). 
о фактах социального сиротства детей в ТНР того времени нет. Это явление возникнет в тувинском обществе гораздо позже, в советский период истории Тувы.

В 1930 г. в ТНР был принят «Закон о браке, семье, опеке над сиротами, недееспособными (душевнобольными) несовершеннолетними и совершеннолетними». Этот закон уже содержал норму, которая гласила: «Если родители не будут выполнять родительские обязанности, или нанесут страдание детям через жестокое обращение, решением суда можно изъять детей и передать в учреждения присмотра, а расходы на содержание детей взыскивать с имущества родителей через суд»${ }^{1}$

В соответствии с Уголовным уложением ТНР от 1930 г. для женщин было введено отдельное от прочих заключенных содержание, для беременных женщин при исполнении уголовного наказания была предоставлена отсрочка на 2 месяца до родов и на 2 месяца после родов (НА РТ, ф. 93, оп. 1, д. 13, л. 3, п. 16).

В особенную часть уложения в раздел «Убийство» было включено понятие аборта, совершенное при определенных условиях, как уголовное преступление: «Совершенное с согласия матери изгнание плода лицами, не имеющими на это надлежащей медицинской подготовки или хотя бы имеющими таковую, если в виде промысла или без согласия матери или имели последствия - смерть - лишение свободы на срок до 5 лет, в противосанитарной обстановке - лишение свободы или принудительные работы до 1 года или штраф до 5000 рублей» (НА РТ, ф. 93, оп. 1, д. 13, л. 20, п. 164).

По сравнению с уголовным законом ТНР 1927 г. в Уголовном уложении 1930 г. было ужесточено наказание за принуждение к занятию проституцией, сводничество, содержание притонов разврата, а также вербовка женщин для проституции. За эти действия было предусмотрено лишение свободы до 5 лет с конфискацией всего или части имущества (там же: л. 23, п. 189).

Смягчению подверглось содержание нормы, запрещающей вступление в брак или небрачное сожительство лиц, состоящих в родственной связи по восходящей и нисходящей линии. Если в уголовном законе 1927 г. была указана недопустимость связей в рамках четырех поколений, то в уложении 1930 г. - до третьего колена включительно. За нарушение этой нормы, а также за связи полнородных и неполнородных братьев с сестрами и наоборот, нарушители закона лишались свободы до 2 лет, что также больше, чем в законе 1927 г., в котором указан максимальный срок - до 1 года.

Что касается брачного поведения граждан ТНР, Уложение 1930 г. защищало моногамный брак, за двоеженство и многоженство следовало наказание в виде принудительных работ до 1 года или штраф до 1 тысячи рублей.

Была также введена новелла как «принуждение женщины ко вступлению в половую связь или к удовлетворению половой страсти в иной форме лицом, в отношении которого женщина являлась материально или по службе зависимой» (НА РТ, ф. 93, оп. 1, д. 13, л. 23, п. 192). За данный вид преступления лишали свободы до 5 лет (там же).

Что касается добровольности брачных отношений мужчины и женщины, Уложение указывало на недопущение принуждения женщины или мужчины не только к вступлению в брак, но и принуждения к продлению брачного сожительства (там же: л. 23, п. 193).

За заражение другого лица венерической болезнью лицом, знавшим о наличии у него этой болезни, нарушителей ждала теперь уже не уплата штрафа, а реальное лишение свободы до 3 лет (там же: л. 32, п. 194).

Особое внимание было уделено запрету ранних браков для женской половины. За вступление в брак с лицом, не достигшим брачного возраста, делинквет (виновный) лишался свободы до 2 лет, а за брак с лицом, не достигшим половой зрелости или принуждение к заключению такого брака - до 8 лет (там же: л. 23, п. 189).

Уплата и принятие выкупа невесты были приравнены к преступлению, за которое Уголовное уложение ТНР 1930 г. предусматривало лишение свободы или принудительные работы до 1 года (там же: п. 222). Выкуп был социальной и юридической нормой, столетиями практиковавшейся среди кочевников. Понятие выкупа в семейно-брачных правоотношениях у кочевников имело долгие исторические корни. Генезис материальных условий заключения брака у тувинцев или традиционного

\footnotetext{
${ }^{1}$ Asssak kadaj polcur polgas eq iștinde kizilernin tugajь, paza eskys polgas xar cetpeen ijik-pe, xar cetken polza-taa soluu aarьqlьq kizilerni xaragalzap kamgalaar tyrym [Закон о браке, семье, опеке над сиротами, недееспособными (душевнобольными) несовершеннолетними и совершеннолетними лицами]. Кьzы, 1932. С. 46. (На тув. яз.).
} 
свадебного обряда тувинцев сүй-белек тудар, аас-белек тудар (сунар) подробно исследован С. М. Бичеоол (Биче-оол, 2018: 49). Н. А. Сердобов, например, на основе полученных данных от информаторов в Туве в ходе полевого исследования считал, что в Туве бытовал институт калыма (Сердобов, 1971: 182).

Необходимо отметить, что регулирование размеров выкупа в зависимости от социального статуса брачующихся можно найти в письменных монгольских и цинских законах, основанных во многом на обычном праве кочевых народов. Обращение к сборникам права этих периодов позволяет увидеть особенности семейных и брачных отношений, в которых понятие и размер выкупа имели существенное значение. Они устанавливали размеры выкупа в соответствии с существовавшей в то время социальной иерархией ${ }^{1}$.

Достаточно сильной трансформации подвергся Уголовный закон (TAR kriminel (eruu) tyrymy - Криминальный (уголовный) закон ТНР) в редакции от 14 октября 1934 г., отменивший Уголовное уложение ТНР от 30 июня 1930 г. В примечании к Уголовному закону 1934 г. указывалось на то, что «расстрел как мера прямого подавления применяется в ТАР в исключительных случаях, в отношении особо опасных правонарушителей»². К расстрелу не могли быть приговорены лица, не достигшие 18 лет, и женщины, находящиеся в состоянии беременности ${ }^{3}$.

В Уложении 1930 г. любое поражение прав, в том числе и лишение родительских прав, не могло превышать 5 лет. Уголовный закон 1934 г. прописал, что «лишение родительских прав, т. е. права воспитывать детей и распоряжаться их долей имущества и дохода применяется бессрочно в случаях систематического избиения детей, развращения их, преступно небрежного, угрожающего жизни и здоровью детей содержания»4. Другими словами, лишение родительских прав как один из видов поражения прав по Уголовному уложению 1930 г. не могло длиться более 5 лет, а в 1934 г. мы видим ужесточение наказания путем введения бессрочного лишения родительских прав при определенных обстоятельствах, которые выше указаны.

Уголовный закон в редакции 1934 г. причислил преступления, связанные с «содержанием притонов разврата, вовлечением женщин в проституцию, а равно принуждением кого-либо к занятию проституцией» ${ }^{5}$ к особо опасным преступлениям против порядка управления. К особо опасным преступлениям против жизни и личного достоинства граждан было отнесено «принуждение женщины к половой связи путем использования ее материальной и служебной зависимости» ${ }^{6}$. Такую же формулировку мы находим в статье 154 Уголовного кодекса РСФСР 1926 г.

Уголовный закон ТНР 1934 г. ужесточает наказание за инбридинг (кровосмесительные браки). Так, вступление в брак или сожительство лиц, состоящих в родственной связи по восходящей и нисходящей линии до третьего колена, а также полнородных и неполнородных братьев с сестрами (кровосмешение), влекло за собой лишение свободы без строгой изоляции на срок до двух лет7. В уголовном кодексе 1941 г. происходит послабление, и этот вид преступления описан как «кровосмешение, т. е. половое сношение мужчины с женщиной, состоящих между собой в тех пределах родства, в которых запрещено вступление в брак», и предусматривало исправительные работы до 1 года 8

Фактор «обмана» в склонении женщин к половым отношениям остается, как и в уголовном кодексе 1927 г., преступным, однако причисляется к «менее опасным преступлениям против личного

${ }^{1}$ Их Цааз («Великое Уложение»). Памятник монгольского феодального права XVII в. : пер. С. Д. Дылыкова. М.: Восточная литература, 1981. Ст. 50-56; Уложение Китайской Палаты Внбшнихъ Сношеній : перевелъ с маньчжурскаго С. ЛиповцовЪ. Санктпетербургъ: типографія департамента народнаго просвЂщенія, 1828. Т. I. Глава XX. «О браках», отделение второе. С. 327; Восемьнадцать степных законов: Памятник монгольского права XVI-XVII вв.: Монгольский текст, транслитерация монгольского текста / отв. ред. Е. И. Кычанов; пер. с монг., комментарии и исслед. А. Д. Насилова. СПб.: Петербургское востоковедение, 2002. 159 с.: Восемнадцать степных законов: Памятник монгольского права XVI-XVII вв. СПб.: Петербургское востоковедение, 2002; Рязановский В. А. Монгольское право (преимущественно обычное): ист. очерк. Харбин: Тип. Н. Е. Чернышева. 1931.306 с.; Халха Джирум : Памятник монгольского феодального права в XVIII в. / сводный текст и пер. Ц. Ж. Жамцарано; подготовка текста к изданию, ред. перевода, введ. и примеч. С. Д. Дылыкова. М.: Наука, 1965. 340 с.

${ }^{2}$ TAR kriminel (eruu) tyrymy [Уголовный закон THР]. Кьzьl, 1934. С. 2. (На тув. яз.).

${ }^{3}$ Там же. С. 24. (На тув. яз.).

${ }^{4}$ Там же. С. $28-29$.

${ }^{5}$ Там же. С. 39.

${ }^{6}$ Там же. С. 24.

${ }^{7}$ Там же. С. 48.

${ }^{8}$ TAR kezemce tyrymy [Уголовный кодекс THР]. Кьzы, 1942. С. 130. (На тув. яз.). 


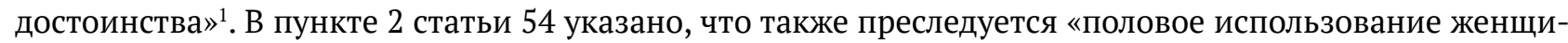
ны путем обещания жениться или иным обманным путем с использованием предрассудков, темноты и невежества потерпевшей»².

В перечислении виктимных условий, то есть условий и обстоятельств, которые способствуют становлению жертвы, как наличие предрассудков, темноты и невежества у женщин, которые преступник может использовать при совершении противоправных действий в отношении них, авторы тувинского закона были оригинальны и передавали социокультурные реалии, в которых находились женщины в молодом государстве. Речь идет о необразованности тувинских женщин в то время. Активная ликвидация безграмотности в целом и среди женщин, в частности, началась только после ввода национальной письменности в 1930 г. В 1931 г., по данным тувинской сельскохозяйственной и демографической переписи, проведенной советскими специалистами, из 82183 человек населения ТНР грамотными был всего 7931 мужчина, из них тувинцев грамотных - 4240 человек; женщин 3007 человек, из них знающих грамоту тувинок - 836 человек ${ }^{3}$. Эти данные свидетельствуют о той культурно-образовательной пропасти и неравных стартовых условиях между тувинскими мужчинами и женщинами, которую не удалось заметно сократить за 10 лет существования ТНР. В дореволюционной Туве женщины фактически не имели доступа к обучению грамоте. Причина была не столько в патриархальности взглядов на женщину и в восприятии женщины как неполноценного существа, сколько в отсутствии в Туве светского образования, доступного для женщин. Обучение тувинских женщин грамоте, современным знаниям шло непросто. Поэтому женщин называли все еще темными и невежественными ${ }^{4}$.

То, что составляло традиционные добрачные и брачные ритуалы тувинцев в Уголовном законе ТНР было названо «пережитками родового быта» ${ }^{5}$. Степень тяжести этих преступлений была определена в уголовном кодексе 1934 г. как «менее опасные преступления, составляющие пережитки родового быта» (статья 59) ${ }^{6}$. К ним были отнесены: насильственное похищение женщины или насильственное принуждение женщины к вступлению в брак или к продолжению брачного сожительства, а равно воспрепятствование женщине, достигшей брачного возраста, выйти замуж по желанию, уплата выкупа за невесту или принятие такого выкупа деньгами, скотом или другим имуществом либо личным трудом, двоеженство и многоженство. За эти деяния полагались принудительные работы до одного года ${ }^{7}$.

Изучая возможности и причины группирования указанных действий под названием «пережитков родового быта, нельзя обойти вниманием Уголовный кодекс РСФСР, который впервые вступил в силу в 1922 г. и был отменен в 1926 г. в связи вступлением в силу Уголовного кодекса 1926 г. В уголовном кодексе 1922 г. такие преступления назывались «бытовыми преступлениями», в кодексе 1926 г. «пережитками родового быта»8.

В главе 10 уголовного кодекса РСФСР 1926 г. содержится 11 статей, описывающих преступления, составляющие пережитки родового быта, в том числе и те, которые не были заимствованы в Уголовном законе ТНР 1934 г., возможно, по причине их несвойственности для тувинского общества того времени. Например, преступления, связанные с кровной местью, такие, как принятие имущественного вознаграждения, уплачиваемого убийцей, его родителями, родичами или родом родителям, родичам, или роду в качестве выкупа, освобождающего от мести или законного преследования. Действие этой

\footnotetext{
${ }^{1}$ TAR kezemce tyrymy [Уголовный кодекс THP]. Кьzьl, 1942. С. 130. (На тув. яз.).

${ }^{2}$ TAR kriminel (eruu) tyrymy [Уголовный закон THP]. Кьzы, 1934. (На тув. яз.). С. 62.

3 Тувинская сельскохозяйственная и демографическая перепись 1931 года. М.: Научно-исследовательская ассоциация по изучению национальных и колониальных проблем. 1933. С. 11-18.

${ }^{4} 1930$ durar on 11 sara-yin 4 - düger edüre ekelen huraldursan Tiva arad risbublig-un bürin erkeber dolodurar yeke hural -un tobči togtaral [Постановление VII Великого Хурала ТНР, 4 ноября 1930 г.]. Кызыл, 1931. С. 72.

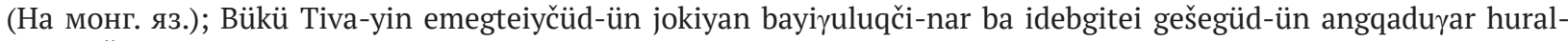
un tobči toqtayal [Постановление первого организационного собрания активных женщин]. Кызыл, 1930. С. 9. (На монг. яз.); Biden-u tiva-yin emegteyčüd-ün urid edüge- yin baidal [Прошлое и настоящее тувинских женщин] // Hubisralči Arad. Duraar dőrben [Революционный арат]. Кызыл, 1929. № 4. С. 22. (На монг. яз.).

${ }^{5}$ TAR kriminel (eruu) tyrymy [Уголовный закон ТНР]. Кьzы, 1934. (На тув. яз.).

${ }^{6}$ Там же. С. 66.

${ }^{7}$ Там же.

8 Уголовный кодекс РСФСР в ред. 1926 г. [Электронный ресурс] // Электронная библиотека. URL: https://bookscafe. net/read/rf_zakony-ugolovnyy_kodeks_rsfsr_v_redakcii_1926_g-180789.html\#p1 (дата обращения: 26.11.2020).
} 
главы, согласно п. 205, распространялось на те автономные области и другие местности РСФСР, где общественно-опасные действия, перечисленные в главе, являлись пережитками родового быта среди проживающих на данной территории национальностей ${ }^{1}$. К ним относились башкиры, народы Кавказа, калмыки и другие национальности. В тувинском уголовном кодексе практически слово в слово были воспроизведены 3 вида преступлений из кодекса РСФСР (таб. 1).

Таблица 1. Преступления, квалифицированные как пережитки родового быта.

Table 1. Felonies classified as 'tribal holdovers'.

\begin{tabular}{|c|c|}
\hline Уголовный кодекс РСФСР 1926 г. & Уголовный закон ТНР 1934 г. \\
\hline $\begin{array}{l}\text { Ст. 196. Уплата выкупа за невесту (калыма), про- } \\
\text { изведенная женихом, его родителями, родичами } \\
\text { или свойственниками родителям, родичам или } \\
\text { свойственникам невесты деньгами, скотом или } \\
\text { другим имуществом, либо личным трудом. }\end{array}$ & $\begin{array}{l}\text { Уплата выкупа за невесту (калым) или принятие такого } \\
\text { выкупа деньгами, скотом или другим имуществом } \\
\text { либо личным трудом. }\end{array}$ \\
\hline $\begin{array}{l}\text { Ст. 197. Принуждение женщины ко вступлению в брак } \\
\text { или к продолжению брачного сожительства, а равно } \\
\text { похищение ее для вступления в брак. }\end{array}$ & $\begin{array}{l}\text { Насильственное похищение женщины или насиль- } \\
\text { ственное принуждение женщины к вступлению в брак } \\
\text { или к продолжению брачного сожительства. }\end{array}$ \\
\hline Ст. 199. Двоеженство или многоженство & Двоеженство и многоженство. \\
\hline
\end{tabular}

Таким образом, в этой части уголовного кодекса ТНР 1934 г. наблюдается выборочное принятие норм советского уголовного законодательства с учетом специфики и реалий в социальных отношениях в тувинском обществе.

Уголовный кодекс 1941 г., сохраняя нормы предыдущих редакций закона, касающиеся защиты прав женщин, внес ряд новелл. Он отменил редакцию закона 1934 г., во многом стал более суровым в силу разных исторических обстоятельств. Это и непростая международная обстановка в мире, японская агрессия в Азии, и начало II мировой войны. Высшая мера наказания - расстрел - сохраняется, исключение также составляют несовершеннолетние и беременные женщины.

Новым в законе явилось включение в число преступлений против государственного управления такого вида действия, как «воспрепятствование женщине в осуществлении ею равных прав, представленных Конституцией ТНР в области хозяйственной, государственной, культурной и в общественнополитической жизни»², если это воспрепятствование проявлено не в контрреволюционных целях, влечет за собой исправительные работы на срок до шести месяцев 3 .

По сравнению с предыдущими редакциями в уголовном кодексе 1941 г. за преступления, связанные с абортами, которые классифицированы как преступления против личности (производство аборта, производство абортов в виде промыслов, содействие аборту, понуждение женщины к аборту, самоаборт), установлено наказание также самой беременной женщине: в первый раз - общественное порицание, при вторичном нарушении - штраф в размере 250 акша 4 . Запрещены были «недозволенные аборты» за исключением случаев, когда была угроза жизни или тяжелые последствия для здоровья матери, угроза тяжелых наследственных болезней. Однако полного запрета абортов, как в СССР, не было. В СССР аборты были запрещены в 1936 г. Постановлением ЦИК СССР (№65) и СНК СССР (№1134) от 27 июня 1936 г. «О запрещении абортов, увеличении материальной помощи роженицам, установлении государственной помощи многосемейным, расширении сети родильных домов, детских яслей и детских садов, усилении уголовного наказания за неплатеж алиментов и о некоторых изменениях в законодательстве о разводах», которое утратило силу только в 1968 г. ${ }^{5}$ Как видно из названия и

\footnotetext{
${ }^{1}$ Уголовный кодекс РСФСР в ред. 1926 г. [Электронный ресурс]//Электронная библиотека.URL: https://bookscafe. net/read/rf_zakony-ugolovnyy_kodeks_rsfsr_v_redakcii_1926_g-180789.html\#p1 (дата обращения: 26.11.2020).

${ }^{2}$ TAR kezemce tyrymy [Уголовный кодекс ТНР]. Кьzы, 1942. С. 118. (На тув. яз.).

${ }^{3}$ Там же.

${ }^{4}$ Там же. С. $126-127$.

${ }^{5}$ Постановление ЦИК СССР (№ 65) и СНК СССР (№ 1134) от 27 июня 1936 г. «О запрещении абортов, увеличении материальной помощи роженицам, установлении государственной помощи многосемейным, расширении сети родильных домов, детских яслей и детских садов, усилении уголовного наказания за неплатеж алиментов и о некоторых изменениях в законодательстве о разводах» [Электронный ресурс] // КонсультантПлюс. URL: http://www.consultant.ru/cons/cgi/online.cgi?req=doc \&base=ESU \&n=4068\#09359441751273434 (дата обращения: 25.11.2020).
} 
содержания советского постановления, оно носило, прежде всего, демографическое значение, то есть включало в себя пакет мер, направленных на поддержку рождаемости в стране и соответствующей социальной инфраструктуры. Следует отметить, что в партийных документах ТНР указанного периода демографическая проблема поднималась только в контексте борьбы с социальными болезнями, а вопросы повышения рождаемости отдельно не поднимались. Полагаем, что ограничение абортов носило превентивный характер, или было перенесено автоматически из советских законов, поскольку аборты не могли быть широко распространены в ТНР из-за недостаточной развернутости сети медучреждений, нехватки врачей (например, врачей в Туве в 1931 г. насчитывалось всего 6, в 1944 г. 15 чел. $\left.{ }^{1}\right)$.

Еще одним новшеством стало содержание 175 статьи: к хозяйственным преступлениям был причислен отказ в приеме на работу женщин по мотивам беременности или снижение им заработной платы по тем же мотивам. Такие действия влекли за собой исправительные работы на срок до 6 месяцев или штраф до 200 акша².

K преступлениям против порядка управления было причислено сокрытие обстоятельств, препятствующих вступлению в брак, а равно сообщение заведомо ложных сведений органам, ведущим регистрацию актов гражданского состояния ${ }^{3}$.

В уголовном кодексе 1941 г. сохраняются преступления, составляющие пережитки родового быта, указанные в уголовном законе 1934 г.: насильственное похищение женщины для вступления с ней в брак против ее воли; принуждение женщины ко вступлению в брак или продолжению брачного сожительства, уплата выкупа (калыма) или принятие такого выкупа деньгами, скотом или другим имуществом, либо личным трудом ${ }^{4}$.

Подытоживая сказанное нужно отметить, что уголовные законы ТНР через запретительные и предупредительные меры устанавливали новый социальный порядок в тувинском обществе. Наряду с другими законами они стали источником новых социальных норм, предъявили гражданам, в том числе тувинским женщинам, новые ценностно-нормативные требования, санкционируя и запрещая определенные типы поведения. Были упорядочены в возрастном измерении добрачные связи, укреплен институт семьи. Вступление в брак с установленного возраста было упрощено за счет запрета традиционных материальных условий заключения брака - таких, как уплата выкупа, обмен подарками, скотом, отработка будущего зятя в хозяйстве родителей невесты.

Уголовное законодательство защищало женщин от разных видов насилия, принуждения, использования их в качестве объекта для получения дохода (через запрет проституции). Отдельные нормы влияли на улучшение здоровья женщин, населения ТНР в целом, и имели демографическое значение для тувинского общества. Например, уголовная ответственность за распространение социальных болезней или запрет инбридинга. Не случайно в этот период мы видим существенный естественный прирост коренного населения ТНР: 1921 г. тувинское население составляло 50,0 тыс. чел., в 1931 г. 82,2 тыс. чел., в 1945 г. - 85,7 тыс. чел. ${ }^{5}$ Безусловно, такие темпы естественного прироста были обусловлены не только этим фактором, но и целым комплексом других, в том числе: санитарным просвещением, внедрением европейской медицины, разворачиванием сети больниц, работой медицинских юрт-передвижек.

Следует указать на то, что уголовное законодательство ТНР также способствовало эмансипации социализации женщин. Как выше показано, некоторые нормы исключали половую сегрегацию в трудовых отношениях, дискриминацию беременных женщин при приеме на работу, оплате труда, склонение женщин к близости через использование материальной или служебной зависимости женщин. А воспрепятствование культурной, политической, экономической социализации женщин стало караться законом. Эти нормы, как мы полагаем, способствовали установлению фактического равноправия женщин в тувинском обществе.

Поскольку конституции ТНР, как показано выше, задекларировали равноправие полов перед законом, женщины несли такую же ответственность, как и мужчины. В уголовном правосудии ТНР

\footnotetext{
${ }^{1}$ Тува за 80 лет. Юбилейный статистический сборник. Кызыл: Государственный комитет Республики Тыва по статистике, 2001. С. 12.

${ }^{2}$ TAR kezemce tyrymy [Уголовный кодекс THP]. Кьzы, 1942. С. 126-127. (На тув. яз.).

${ }^{3}$ Tам же.

${ }^{4}$ Там же. С. 78.

${ }^{5}$ Тува за 80 лет.... С. 28.
} 
единственные послабления для женщин мы видим только в том, что расстрелу неподлежали беременные женщины, при исполнении уголовного наказания беременным женщинам давали отсрочку, а также оговаривалось отдельное содержание женщин при заключении.

Государство в интересах защиты детей получило возможность вмешиваться во внутрисемейные отношения, и подвергать поражению прав в виде лишения родительских прав родителей, в то числе женщин-матерей.

Говоря о влиянии советского права на законотворчество в ТНР, не нужно забывать о том, что в ТНР был институт советников из СССР и работали представители Коминтерна, которые оказывали воздействие на все стороны жизни тувинского общества. В частности, они принимали участие в разработке проектов тувинских законов. Так, например, в политическом докладе о работе в Туве председатель Полномочной Комиссии ЦИК СССР для Урянхайского края и Чрезвычайный полномочный представитель Я. Х. Давтян, который ездил в ТНР после восстания на Хемчике 1924 г., писал в ЦК РКП, Нарком Иностранных дел, полномочным представителям СССР в Китае и Монголии о том, что «советники и инструктора для Танну-Тувинского правительства и Танну-Тувинской революционной партии должны быть подбираемы тщательно. Вся законодательная работа Танну-Тувинского правительства должна регулироваться через этих лиц, которые подчиняясь неофициально консулу СССР, должны следовать ему неуклонно» (РГАСПИ, ф. 495, оп. 153, д. 1, л. 27-28). Непосредственное отношение к процессу разработки законов ТНР имели также представители Коминтерна. В. Богданов, представитель Исполнительного комитета Коммунистического Интернационала (ИККИ) в ТНР в 1930 г. писал в Восточный отдел ИККИ о том, что «все судебное законодательство Тувы в ближайшее время будет переработано в соответствии с принципами советского законодательства» (РГАСПИ, ф. 495, оп. 153, д. 37, л. 11).

\section{Защита прав женщин в гражданских законах ТНР}

Говоря о становлении правового статуса тувинских женщин в период ТНР, отдельно следует остановиться на законе «О браке, семье, опеке над сиротами, недееспособными несовершеннолетними и совершеннолетними» 1930 г. Закон по содержанию является аналогом современных семейных кодексов, он отразил серьезные трансформации, происходившие не только в общественном, государственном уровнях, но и в личной жизни тувинских женщин, в отношениях с мужским полом, детьми, родственниками. Здесь речь идет не только о правах, но и об обязанностях.

Bo-nервых, браки между мужчиной и женщиной стали регистрировать государственные органы. То есть законными стали считаться те браки, которые имеют государственную регистрацию. Регистрировали органы местного самоуправления - хошунные, сумонные Советы. До принятия указанного закона был промежуточный период, когда тувинцы уже отказались от цинских законов, а браки заключались в соответствии с народными традициями. Рассматриваемый закон же утвердил условия регистрации брака, а также обстоятельства, при которых регистрация невозможна. Принцип добровольности вступления в брак закреплен здесь отсылкой к уголовному закону: «человека, не желающего вступать в брак, ни родители, ни родственники не могут насильно заставлять вступать в брак. За нарушение будут судить в соответствии с уголовным законом» .

В основе условий регистрации лежал принцип добровольности и зрелости по возрасту - оба должны быть согласны на брак и быть совершеннолетними (старше 18 лет). Факторами, препятствующими регистрации брака, закон назвал наличие у одного из брачующихся зарегистрированного или незарегистрированного, но фактического брака, наличие у одной из сторон свидетельства о том, что является душевнобольным или умственно отсталым, а также если брачующиеся являются родственниками в третьем поколении ${ }^{2}$.

Признание гражданского брака, а также незарегистрированного фактического сожительства как брачных отношений и запрет регистрации нового брака при их наличии означало объявление двоеженства, многоженства, которое было вне закона. Следует отметить, что в начале XX в. этнографы находили примеры двоеженства в тувинских семьях, вместе с тем подчеркивая, что такое явление не

\footnotetext{
${ }^{1}$ Asssak kadaj polcur polgas eq istinde kizilernin tugajb, paza eskys polgas xar cetpeen ijik-pe, xar cetken polza-taa soluu aarьqlьq kizilerni xaragalzap kamgalaar tyrym [Закон о браке, семье, опеке над сиротами, недееспособными (душевнобольными) несовершеннолетними и совершеннолетними лицами]. Кьzы, 1932. С. 7. (На тув. яз.).

${ }^{2}$ Там же. С. 6.
} 
было повсеместным. Например, Ф. Кон описывает свое посещение почитаемого шамана ХабакшанХама в устье Сыстыг-Хема, который был двоеженцем. Две жены жили в отдельных юртах, старшая из них заведовала скотоводческим хозяйством, младшая - оленеводческим. Этнограф отмечает отсутствие антагонизма и вражды между женами шамана (Кон, 1934: 250). По его сведениям, двоеженство было возможно в двух случаях: бесплодие жены и отсутствие мальчиков среди рожденных первой женой детей (там же: 137).

Во-вторых, закон запретил калым: «воспрещается принимать подарки, скот девушке от жениха, его родителей, родственников. Если нарушат норму и примут подарки (sej pelek), будут их судить и наказывать в соответствии с уголовным законом»1.

$B$-третьих, даже в условиях заключенного брака супруги, согласно этому закону, могли выбирать место жительства. Традиционно жена в тувинской семье следовала за мужем и проживала в родовых местах мужа. Такие браки назывались патрилокальными. Это было связано с экзогамностью браков тувинцев: невест брали из другого аала, и отдавали девушек в другой аал (Потапов, 1969: 127), а также патриархатными отношениями в тувинском обществе и кочевым образом жизни. У тувинцев, например, был обряд дүгдээшкин, при котором невесту готовили к тому, что она уедет из родных кочевий в аал мужа (Биче-оол, 2018: 58-59). Когда наступало время отъезда, из аала мужа приезжал мужчина, который ее увозил (там же: 63). Закон 1932 г. в части прав и обязанностей прямо указывал на то, что «если кто-то из поженившихся захочет ехать в другое место жительства, а другая сторона не хочет, не стоит последнего заставлять»².

$B$-четвертых, регулирование имущественных прав супругов как в зарегистрированном браке, так и при фактическом, но незарегистрированном браке ${ }^{3}$, понятие совместно нажитого имущества в виде скота - было включено в содержание закона. Так, скот, составлявший имущество супругов до брака, остается их собственностью, скот, появившийся после брака - их совместным имуществом. При разводе имущество рекомендовалось поделить договоренности между собой. В случае, если стороны не могли договориться, решение принимал суд ${ }^{4}$.

Закон предусматривал возможность заключения «брачного договора» по имущественным вопросам. В тексте закона говорилось о том, что «супруги могут заключать между собой договор, не противоречащий закону, относительно своего имущества, но если при подписании договора будут нарушены права одного из брачующихся, этот человек может уничтожить договор» ${ }^{5}$.

В-пятых, закон в п. 20 дал возможность развода, ввел регистрацию разводов. Супруги могли по договоренности развестись, если кто-то из супругов не хотел дальше жить, принять согласованное решение о том, с кем будут жить дети, кто и в какой степени будет их содержать. В ином случае эти вопросы решал суд

B-шестых, закон в пп. 29, 30, 32, 33 установил процедуру установления отцовства, если ребенок рожден вне брака ${ }^{7}$ Мать ребенка должна была сообщить в орган регистрации об отце ребенка, предполагаемого отца уведомляли об этом. В течение месяца после получения информации он должен либо подтвердить, либо опровергнуть информацию о том, является ли он отцом родившегося ребенка. Если от предполагаемого отца не поступает никакой информации, его регистрируют как отца. Оспорить регистрацию в качестве отца он мог в течение года через суд. После установления отцовства через суд отец должен был возместить расходы женщины во время беременности, после рождения ребенка на его содержание. В течение 6 месяцев после рождения отца ребенка заставляли оплачивать расходы женщины. В этом разделе тувинского закона о семье, браке и опеке можно увидеть

\footnotetext{
${ }^{1}$ Asssak kadaj polcur polgas eq isstinde kizilernin tugajb, paza eskys polgas xar cetpeen ijik-pe, xar cetken polza-taa soluu aarьqlьq kizilerni xaragalzap kamgalaar tyrym [Закон о браке, семье, опеке над сиротами, недееспособными (душевнобольными) несовершеннолетними и совершеннолетними лицами]. Кьzьl, 1932. С. 6. (На тув. яз.).

2 Там же. С. 7.

3 Для защиты имущественных супругов закон предусматривал возможность легализации незарегистрированных браков через суд. Если в суде мужчина и женщина докажут, что вели совместное хозяйство, поддерживали друг друга, защищали, совместно воспитывали своих детей. Если связь была доказана, в этом случае они приравнивались к супругам.

${ }^{4}$ Asssak kadaj polcur ... C. 8.

${ }^{5}$ Там же. С. 9.

${ }^{6}$ Там же. С. 10.

${ }^{7}$ Там же.
} 
зарождение истории алиментских обязательств в тувинском обществе. В традициях тувинцев ранее не было практики взыскания финансовой поддержки со стороны биологических отцов для содержания внебрачных детей. С этой точки зрения введенный законом пункт установил совершенно новую социальную норму поддержки внебрачных детей.

В случаях, когда возникали трудности с установлением отцовства, на суде допрашивали мужчин, кто мог бы быть отцом, о чем было прописано в п. 33 пятой главы указанного закона ${ }^{1}$.

Правовая картина будет неполной, если не упомянуть о законах о труде, которые принимались в ТНР в 1929, 1933, 1938, 1942 гг.

В данных законах прослеживается эволюция мер, направленных на облегчение условий труда женщин. К примеру, такой показатель, как частота перерывов для кормящих матерей, увеличивается в более поздней редакции. Если в Законе о труде, принятом в 1933 г., матерям, кормящим грудью, в течение 9 месяцев с момента рождения ребенка перерыв предоставлялся один раз в день продолжительностью полчаса, то в законе 1938 г. перерывы установлены в каждые три часа. В этой же редакции закона появились новые нормы, касающиеся труда женщин: беременных женщин и кормящих матерей не стали допускать к ночной работе и вредному производству². B самих текстах законов о труде мы не находим прямых запретов заниматься теми или иными производствами, распространяющихся на женщин, кроме как недопущения беременных и кормящих женщин к вредным производствам. К Закону о труде 1938 г. приложены списки особо вредных профессий, дающих право на удлиненный трудовой отпуск, на уменьшение рабочего дня, специальное питание. В их число были включены профессии поломоек вредных цехов, уборщиц, работающих при сортировке пушнины и шерсти, телефонисток, поваров, операционных сестер, нянь и др. Полагаем, что важнейшей задачей для тувинского правительства было вовлечение женщин в народное хозяйство, производство, экономику страны, так как они с демографической точки зрения были почти половиной населения Тувы и представляли собой нераскрытый, неиспользуемый в полной мере трудовой потенциал.

Было установлено, что беременность не является причиной для отказа в приеме на работу, а также были четко урегулированы сроки отпуска по беременности․․ При беременности и родах женщины, работавшие по найму, пользовались оплачиваемыми отпусками до и после родов ${ }^{4}$ При выполнении одинаковых работ с мужчинами труд женщин должен был оплачиваться не ниже, чем у мужчин 5 .

Законы о труде ТНР свидетельствуют о том, что в первую очередь учитывались репродуктивные функции женщин, особые состояния, связанные с вынашиванием, рождением и кормлением ребенка. Нормы закона, регулирующие порядок оплаты труда, носили антидискриминационный характер в отношении женщин

По этим законам мы видим, что впервые за историю Тувы возникает класс наемных работающих женщин в социальной структуре общества. Первая сельскохозяйственная и демографическая перепись в ТНР была проведена в 1931 г. усилиями большой группы исследователей Научно-исследовательской ассоциации по изучению национальных и колониальных проблем по просьбе Государственной плановой комиссии ТНР. По данной переписи можно увидеть зарождение социально-профессиональной структуры тувинского общества. Так, в структуре общества мы видим класс рабочих: среди них 1609 мужчин и 1193 женщин, служащих - 957 мужчин и 866 женщин 6

Тувинские женщины, обретая политические знания, стали принимать участие в политике, избираться в выборные должности, все более внедряясь в партию, революционный союз молодежи,

\footnotetext{
${ }^{1}$ Asssak kadaj polcur polgas eq isstinde kizilernin tugajb, paza eskys polgas xar cetpeen ijik-pe, xar cetken polza-taa soluu aarbqlьq kizilerni xaragalzap kamgalaar tyrym [Закон о браке, семье, опеке над сиротами, недееспособными (душевнобольными) несовершеннолетними и совершеннолетними лицами]. Кьzь, 1932. С. 10 (На тув. яз.). ${ }^{2}$ Tьbа Arat Respubliktьп kyş-azыl tyrymy [Закон о труде THP]. Kьzы: TAR Picce Xural Prezidiymynyп ceri, 1939. С. 116. (На тув. яз.).

${ }^{3}$ Закон о труде. Кызыл: Гостипография, 1933. С. 10; Тьbа Arat Respubliktьฤ kyş-azы tyrymy [Закон о труде ТНР]. Kьzbl: TAR Picce Xural Prezidiymynyп ceri, 1939. С. 116. (На тув. яз.).

${ }^{4}$ Закон о труде. Кызыл: Гостипография, 1933. С. 19.

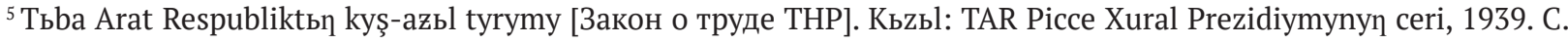
117. (На тув. яз.).

${ }^{6}$ Тувинская сельскохозяйственная и демографическая перепись 1931 года. М.: Научно-исследовательская ассоциация по изучению национальных и колониальных проблем, 1933. С. 5.
} 
кооперацию, профессиональные союзы. В 1932 г. в работе IX съезда ТРНРП из 149 делегатов 31 делегат был представлен тувинскими женщинами ${ }^{1}$. Из 6053 членов ТНРП в 1941 г. 1572 были женщинамиㄹ․

Женщины были заняты не только в производстве, но и стали заниматься работой, требующей профессиональной подготовки. Как докладывал С. Тока в 1936 г., тувинские женщины работали учителями, счетоводами, машинистками, продавцами, телефонистками, средними медицинскими работниками ${ }^{3}$.

\section{Модернизация VS традиционализм}

Следует отметить, что, говоря о конституционных правах женщин, об особенностях уголовных, гражданских законов ТНР, мы затрагиваем в большей степени формальную сторону правового положения женщин в ТНР. Гораздо более сложными являются вопросы понимания, восприятия тувинским обществом изменений социальных норм не только в отношении женщин, но и всех сфер жизни в целом. Анализ внутриполитической повестки ТНР показывает, что модернизационные процессы (Моллеров, 2010) шли сложно, и «женский вопрос» рассматривался, как правило, на языке критики и самокритики. Эмансипация женщин была одним из главных социальных и политических проектов молодого тувинского государства. Он реализовывался не так гладко и быстро, как хотелось руководству ТНР, и встречал в обществе гласное и негласное противодействие. Женщины не знали в полной мере о своих правах, не знали норм новых законов не только в силу инерции традиционного общества, но и в большей степени по причине массовой неграмотности и необразованности в 1920-е гг. Частота упоминаний «женского вопроса» в материалах съездов и иных документах доказывает, насколько важным было для руководства ТНР не только обучить грамоте, социализировать женщин, но и включить их в политические процессы, в том числе в классовую борьбу, в экономику страны, особенно в военное время, когда от женщин требовались умения и навыки для полной замены мужчин в хозяйстве и экономике, если потребуется.

Сопротивление новой политике, в том числе так называемым «левацким перегибам» осуществлялось, в том числе с оружием в руках. За 23 года существования ТНР, по крайней мере, насчитывается три вооруженных восстания: на Хемчике в 1924 г. (Моллеров, 2017: 42), Хемчикское и Подхребтинское восстание 1930 г. (Самдан, 2020), восстание на Тере-Холе 1932 г. ${ }^{4}$ Активность проявляли Подхребтинская, Тесингольская контрреволюционные группы в 1931 г., Качыкская группа в 1932 г. ${ }^{5}$ Перекочевка вглубь территории Монголии жителей приграничных районов ТНР (территорий современных Эрзинского, Тере-Хольского, Овюрского, Монгун-Тайгинского кожуунов) также была следствием неприятия общественно-политических процессов, происходивших в ТНР.

Необходимо указать на то, что распространение слухов было достаточно эффективным вербальным оружием против нового, способным взбудоражить общество и могло приводить к определенным действиям.

По версии О. Менхен-Хелфена, австрийского синолога, совершившего в 1929 г. поездку в ТНР в сопровождении тувинских студентов КУТВ, обрезание волос у женщин стало одним из поводов для восстания на Хемчике в 1924 г. В «Путешествии в Азитатскую Туву» он писал:

«У восстания на Хемчике 1924 года, в котором приняли участие более 2000 мужчин, было много побудительных причин. Но последней каплей, переполнившей народное терпение, стал слух о том, что правительство по приказу русских собирается заставить женщин носить короткие стрижки. Ни одна из религий не предписывает тувинской женщине носить определенную прическу. И, тем не менее, 2000 мужчин взялись за оружие против вмешательства в древний привычный уклад жизни, против насильственных изменений» (Менхен-Хелфен, 2007: 276).

${ }^{1}$ TARN 9 tugaar ulug xuralınьр rezolustarь [Резолюции IX съезда ТНРП]. Кьzьl: Тьbа kyryneniך nom cogaadьr ceri, 1932. С. 128. (На тув. яз.).

${ }^{2}$ TARN-nьy XII tugaar eelceg cok ulug xuralıjga TARN TK-nьy otcot iletkelinin kol-kol san kergyzygleri [Основные количественные показатели к отчетному докладу ЦК ТНРП на XII внеочередном съезде ТНРП]. Кьzbl: TARN TK, 1941. С. 3-4. (На тувинском языке).

${ }^{3}$ Tока. KOMINTERNANbD VII Tugaar kongrezi polgas TARN sorulgalarb [Тока. VII Конгресс Коминтерна и задачи ТНРП]. Кьzьl: Cogaal Komitedi, 1936. С. 90. (На тув. яз.).

${ }^{4}$ Докладная записка Управления государственной внутренней политической охраны для представления в ЦК АРП и Правительство от 15 августа 1932 г. (РГАСПИ, ф. 495, оп. 153, д. 55. л. 31-32).

${ }^{5}$ Там же. 
Так, одна из первых тувинских женщин, обучавшихся в КУТВ, и сделавших успешную партийную карьеру, Таня Камова (Сат), вспоминала следующий эпизод из своей жизни. В 1923 г. Сат Шогжапай (ее отец) после участия в Великом Хурале вернулся в сумон и начал агитационную работу среди аратов для сбора группы детей, которых нужно было направить на учебу в столицу. Он говорил о революционном подъеме, о большом внимании к вопросам обучения грамоте простых аратов. Однако тут же началась контрпропаганда среди аратов через распространение слухов о том, что девочек 13-15 лет, которые приедут в Хем-Белдири (Кызыл), тотчас отдадут замуж военным. Араты, услышав эти слухи, отказывались отправлять дочерей на учебу, срочно выдавали своих несовершеннолетних дочерей замуж. «Простая аратка, встречая сыновей своих знакомых, спрашивала: не хочешь ли ты жениться на моей дочери?» ${ }^{1}$ После такой контрпропаганды ее отцу не удалось уговорить аратов, чтобы те отправили своих детей на учебу. Поэтому он принял решение о направлении в столицу своей дочери и детей своих близких родственников. Десять человек, в том числе Таня Камова (Сат) отправились осенью 1923 г. В Хем-Белдири (Кызыл) учиться в русскую школу².

Воспоминания известного тувинского писателя Степана Сарыг-оола также свидетельствуют о конфликте традиционных ценностей, культурных и социальных норм с чуждыми и непонятными для большинства тувинцев новациями, которые вызывали страх и чувство неопределенности:

«1926 год. Дикий ажиотаж среди аратов, вопросы, которые волновали родителей: кому отдать замуж дочь, кто придет свататься, она несовершеннолетняя, что делать? Если она не захочет, что делать, кого взять в жены сыну? Дилемма стояла даже перед ревсомольцами: жениться или учиться? Причина была в слухах: говорили, что всех детей забирают и отправляют в Хем-Белдири (Кызыл), в некоторых местах насильно отбирают детей.

“Там дети портятся, с сызмальства не будут знать стыда, ни перед чем не остановятся, только познакомившись, ходят, взявшись за руки, обнимаются, даже игры такие: заигрывают друг с другом, не скрывают своего тела. Потом, когда чуть повзрослеют, уедут в Россию, Бурятию. Дети будут потеряны, без религии, будут есть лягушек, змей, насекомых".

Старшие говорили, надо выделить часть имущества и поженить детей. В этой ситуации молодежь тоже не могли усидеть на месте, все искали своих суженых» ${ }^{3}$.

Показательно обсуждение, которое состоялось после выступления А. М. Амур-Санана, представителя ИККИ в THР, на IV съезде THРП в 1925 г., когда впервые серьезно был поднят вопрос о работе с тувинскими женщинами. Один из вопросов, заданных А. М. Амур-Санану, был следующим: «сли не покупать жен и не платить калым, то как же будут сходиться, по собственному желанию или при участию родителей?» А. М. Амур-Санан ответил: «Отца, брата девицы, выходящей замуж, более всего интересует, сколько они получат денег - выкупа за девицу, а не то, за кого они выдают свою родственницу, будет ли она счастлива. Это делается так, как продавали бы корову или какую-нибудь вещь. Но так делать нельзя, это жестоко, бесчеловечно» ${ }^{5}$ А на вопрос, каким образом привлекать женщин к образованию, когда и из мужчин большинство неграмотно, он ответил: «Если вы насильно отдаете замуж, то тем более можно насильно отдавать в ученье, так как это всем будет в пользу» ${ }^{6}$.

В 1930-е гг. вопрос социализации тувинских женщин не теряет своей остроты. Он приобретает даже большую остроту в контексте антирелигиозной, внутриполитической борьбы в ТНР. При обсуждении «женского вопроса» на заседании ЦК ТНРП в июне 1934 г. вновь звучат утверждения о том, что тувинские женщины в своем развитии серьезно отстают от мужчин, что нужно менять методы работы с ними: отказаться от практики делегатских собраний, воздействовать на женщин через все имеющиеся общественные, хозяйственные структуры (профсоюзы, ТРСМ, кооперация). Критике были подвергнуты и судебные органы за то, что «плохо разбирают дела об издевательствах над женщинами, о нарушениях политико-экономических прав женщин». По итогам обсуждения было принято

\footnotetext{
1 Чалыы назыннын оруу. Тыванын аныяктар организациязынын 40 чыл ою [Дороги молодости. К 40-летнему юбилею Тувинской организации молодежи]. Кызыл: Тувинское книжное издательство, 1965. С. 99.

${ }^{2}$ Там же.

${ }^{3}$ Там же. С. 136-138.

${ }^{4}$ Протокол IV съезда Танну-Тувинской Народно-Революционной партии. 14-19 октября 1925 г. (РГАСПИ, ф. 495, оп. 153 , д. 3 , л. 16).

${ }^{5}$ Там же.

${ }^{6}$ Там же.

${ }^{7}$ Протокол заседания ЦК ТНРП от 27 июня 1934 г. (РГАСПИ, ф. 495, оп. 153, д. 66, л. 46-47).
} 
решение об ознакомлении женщин с конституцией, законами ТНР, с их правовым положением и защитой прав, а также по предложению С. К. Тока в постановление ЦК ТНРП включили поручение о разработке и издании специальной брошюры для женщин на основе Конституции ТНР ${ }^{1}$

Эти разноплановые примеры доказывают то, что принятие новых законов в ТНР не могло в одночасье сломать традиционную модель жизни, что внедрение нового, в том числе через законы, проходило через разные формы сопротивления, неприятия, незнания, непонимания и несоблюдения. Результативность изменений зависела от степени интенсивности внедрения, разъяснительно-просветительской работы и, наконец, от использования насильственных, принудительных методов. Как мы видим, преимуществами своего правового положения, предоставленными законами ТНР, женщины не сразу могли пользоваться на практике, но вместе с тем эти законы дали женщинам новый статус в семье и обществе, новые, ранее недоступные для них горизонты развития.

\section{Заключение}

Рассмотрев правовое положение женщин в ТНР, можно сделать несколько выводов.

В своих законах ТНР ориентировалась преимущественно на советское государство. Эта тенденция со временем усиливалась. С 1930 г. происходит все более масштабная рецепция норм советского законодательства, связанная, в частности, с приходом к власти элиты, получившей образование в СССР и пребывающей под сильным советским влиянием. Вместе с заимствованием советских норм тем не менее принимались нормы и опирающиеся на социокультурные основания в самом тувинском обществе.

Конституции и законы ТНР внесли в жизнь общества новые социальные нормы запрещающего, обязывающего и дозволяющего характера. Конституции ТНР установили общественно-политическое равноправие тувинских мужчин и женщин, дали женщинам избирательные права, равные условия труда и ее оплаты, государственную охрану материнства и детства. Тувинская женщина фактически без борьбы обрела политические права, гражданские свободы, конституционно закрепленное равноправие с мужчинами, доступ к управлению государством, образованию, современному здравоохранению. Социальное и политическое равенство женщин, как государственная политика, артикулировалось, прежде всего, ТНРП и правительством, исходя из политических и социальных задач, которые стояли перед ними. Это как раз то, что исследовали называют «государственным феминизмом» (Бобровская, 2020). Однако эмансипация женщин кочевого общества, которые в дореволюционный период не имели доступа ни к образованию, ни к государственному управлению, была непростой задачей. Юридического закрепления конституционного равенства мужчин и женщин было недостаточно. В этой связи в разные законы, в том числе и уголовные, гражданские, были инкорпорированы нормы, которые давали возможность внедрить в общественную практику новые статусно-ролевые функции для тувинских женщин.

Тувинские женщины в ТНР стали полноправными субъектами права, получили равность правосубъектности с мужчинами в семейных правоотношениях. Уголовные законы ТНР наложили запрет на физическое насилие над женщиной, насильственные браки, раннее замужество, привлечение женщины к занятию проституцией. Кроме того, были введены новая форма регистрации брака, договорное и судебное регулирование имущественных правоотношений супругов при разводе, имущественные отношения при незарегистрированном сожительстве, практика установления отцовства, обязанности биологического отца ребенка, рожденного вне брака.

Таким образом, закон предоставил тувинской женщине свободу выбора в установлении брачных отношений, свободу развода, при котором женщина не обязана была возвращаться под юрисдикцию своего отца, родителей, экономическую защиту через возможность судебного установления отцовства и принудительного возмещения отцом ребенка расходов женщины в связи с беременностью и родами. Женщины получили возможность защищать свои имущественные права при разводе, имущество, накопленное до брака, не включалось в категорию совместно нажитого имущества.

Законы о труде ТНР ввели дифференцированный подход к труду мужчин и женщин, женский труд получил определенные льготы в связи с выполнением репродуктивных функций женщин. Женский труд был включен в производственные отношения, экономику государства. Возникает новый тип работающей по найму женщины с гарантированной государством оплатой труда и трудовыми правами.

\footnotetext{
${ }^{1}$ Протокол заседания ЦК ТНРП от 27 июня 1934 г. (РГАСПИ, ф. 495, оп. 153, д. 66, л. 46-47).
} 
В совокупности и конституции, и уголовные, гражданские законы ТНР явились политико-правовой базой для эмансипации тувинской женщины.

\section{СПИСОК ЛИТЕРАТУРЫ}

Анайбан, 3. В. (2016) Историко-архивные источники о положении женщин-матери в традиционной тувинской семье // Материнство и отцовство сквозь призму времени и культур. Материалы Девятой Международной научной конференции РАИЖИ и ИЭА РАН. 13-16 окт. 2016 : в 2-х т. / отв. ред. Н. Л. Пушкарева, Н. А. Мицюк. М. : Институт этнологии и антропологии им. Н. Н. Миклухо-Маклая. Т. І. 444 с. С. 29-31.

Антонова, А. В. (2008) Основные направления правового регулирования положения женщин в Китае: история и современность // Вестник НГУ. Серия: История, филология. Т. 7, вып. 4. Востоковедение. С. 52-56.

Аранчын, Ю. Л. (1977) РСТК и ТНР // Великий Октябрь и проблемы новейшей истории Тувы / отв. ред. Ю. Л. Аранчын. Кызыл : Тувинский научно-исследовательский институт языка, литературы и истории. 147 с. C. $72-89$.

Башкуев, В. Ю. (2018а) Традиционный быт и проблемы здоровья монгольского аратства в 1920-1930-х гг. (по архивным материалам Наркомздрава РСФСР) // Oriental Studies. Вып. 11(5). C. 14-26. DOI: 10.22162/2619-09902018-39-5-14-26

Башкуев, В. Ю. (2018b) Медико-санитарные экспедиции Наркомздрава РСФСР в Тувинской Народной Республике и становление тувинского здравоохранения (конец 1920-х - середина 1930-х гг.) // Вестник Томского государственного университета. № 426. С. 52-63. DOI: https://doi.org/10.17223/15617793/426/6

Биче-оол, С. М. (2018) Традиционные брачно-семейные отношения у тувинцев и их трансформация в советский период. Абакан : Журналист. 125 с.

Бобровская, Е. В. (2020) «Государственный феминизм» в СССР: особенности гендерного (не) равенства в советской России // Вестник Московского государственного областного университета. Серия: История и политические науки. № 4. C. 133-140. DOI: https://doi.org/10.18384/2310-676X-2020-4-133-140

Вайнштейн, С. И. (1964) К истории ранних форм развития семейно-брачных отношений (ойтулааш у тувинцев) // Советская этнография. № 2. С. 123-124.

Владимирцов, Б. Я. (1934) Общественный строй монголов. Монгольский кочевой феодализм. Ленинград : Издательство Академии Наук СССР. 224 с.

Доржу, 3. Ю. (1993) Социальное положение женщин в Республике Тува. История и современность (1921-1993 гг.) : дисс. ... д-ра ист. н. М. 421 с.

Доржу, 3. Ю. (2008) Женщины Тувы: от прошлого к будущему. Кызыл : Издательство Тувинского государственного университета. 118 с.

Доржу, 3. Ю. (2011)Тувинская семья: Тенденции ее жизнедеятельности // Омский научный вестник. № 1 (95). C. $35-38$

Забелина, Г. А. (1977) Женщины освобожденной Тувы в борьбе за новую жизнь (1921-1944 гг.) // Великий Октябрь и проблемы новейшей истории Тувы. Кызыл : Тувинское книжное издательство. 147 с. С. 90-103.

Забелина, Г. А. (2010) Женщины Тувы в семье и обществе в первой половине XX века. Кызыл : ТувИКОПР СО PAH. 118 c.

История Тувы (2007) / под общ. ред. В. А. Ламина. Новосибирск : Наука. Т. II. 430 с.

Кляшторный, С. Г. (1985) Рабы и рабыни в древнетюркской общине (по памятникам рунической письменности Монголии) // Древние культуры Монголии / отв. ред. Р. С. Васильевский. Новосибирск : Наука. 235 с. С. $159-168$.

Кон, Ф. Я. (1934) Экспедиция в Сойотию. За пятьдесят лет : в 3 т. М.: Издательство Всесоюзного общества политкаторжан и ссыльно-поселенцев. Т. ІІІ. 294 с.

Конституции Тувы 1921-1993 гг. (1999) : сборник к 55-летию принятия Тувы в состав СССР и РСФСР / сост. В. А. Дубровский. Кызыл : Тувинское книжное издательство. 216 с.

Моллеров, Н. М. (2010) О периодизации новейшей истории Тувы с позиции теории модернизации // Сборник материалов II Межд. научно-практической конференции «Кочевые цивилизации Центральной и Северной Азии: история, состояние, проблемы». 01-04 июня 2010 г. Красноярский государственный педагогический университет им. В. П. Астафьева, Тывинский государственный университет. Красноярск : Изд-во Красноярского государственного педагогического университета им. В. П. Астафьева. 360 с. С. 172-176.

Моллеров, Н. М. (2017) История Тувы в 1920-е гг. сквозь призму жизни и деятельности старшего советника тувинского правительства и ЦК ТНРП П. С. Медведева // Oriental Studies. № 3 (31). С. 36-47. DOI: https://doi. org/10.22162/2075-7794-2017-31-3-36-47

Монгуш, М. В. (2010) Тува век спустя после Каррутерса и Менхен-Хельфена. Осака : Национальный музей этнологии. 212 с. 
Менхен-Хелфен, О. (2007) Путешествие в Азиатскую Туву // Урянхай. Тыва дептер : антология : в 7 т. / сост. С. К. Шойгу. М. : Слово. Т. 6.581 с. С. 220-352.

Мурзова, О. М., Жиляева, М. С. (2018) Женщина в политике и власти: социально-исторический анализ // Технологии социальной работы с разными группами населения. Материалы VII Всероссийской научно-практической конференции 04-07 декабря 2018 г. / отв. ред. М. С. Жиляева. Чита : Забайкальский государственный университет. 109 с. С. $88-96$.

Потапов, Л. П. (1969) Очерки народного быта тувинцев. М. : Наука. 401 с.

Почекаев, Р. Ю. (2018) Сведения российских дипломатов XVII в. о монгольском праве // Mongolica-XX. Сборник научных статей к 200-летию со дня основания Азиатского музея / предс. редколлегии И В. Кульганек. СПб. : ИВ PAH. 104 c. C. 21-29.

Прокофьева, Е. Д. (1955) Некоторые этнографические данные о тувинцах западных районов Тувинской автономной области // Краткие сообщения Института Этнографии им. Миклухо-Маклая. Вып. 23. М. : Изд-во Академии наук СССР. 100 с. С. 3-18.

Путешествия в восточные страны Плано Карпини и Рубрука (1957) / ред. и вступ. сл. И. П. Шастиной. М. : Гос. издательство географической литературы. 270 с.

Самдан, А. А. (2020) Вооруженное восстание в Туве в 1930 г. // Новые исследования Тувы. № 3. C. 66-80. DOI: www.doi.org/10.25178/nit.2020.3.5

Сердобов, Н. А. (1971) История формирования тувинской нации. Кызыл : Тувинский научно-исследовательский институт языка, литературы и истории. 484 с.

Сердобов, Н. А. (1985) Коминтерн и революционная Тува. Кызыл : Тувинский научно-исследовательский институт языка, литературы и истории. 238 с.

Темкина, А. А. (2004) Женское движение как общественное движение: история и теория // Гендерная реконструкция политических систем / ред. сост.: Н. М. Степанова, Е. В. Кочкина. СПб. : Институт гендерной политики. 991 c. С. $41-75$.

Цыретарова, Б. Б. (2016) Борьба с социальными болезнями в Бурятии (1920-1940-ые гг.) // Вестник Бурятского государственного университета. № 1. С. 29-35. DOI: https://doi.org/10.18101/2306-753X-2016-1-29-35

Шостакович, С. В. (2007) Политический строй и международно-правовое положение Танну-Тувы в прошлом и настоящем // Урянхай. Тыва дептер. Антология : в 7 т. / сост. С. К. Шойгу. М. : Слово. Т. 6.581 с. С. $182-218$.

Дата поступления: 16.11.2020 2.

\section{REFERENCES}

Anaiban, Z. V. (2016) Istoriko-arkhivnye istochniki o polozhenii zhenshchin-materi v traditsionnoi tuvinskoi sem'e [Historical and archival sources on the status of mothers in the traditional Tuvan family]. In: Materinstvo $i$ ottsovstvo skvoz' prizmu vremeni $i$ kul'tur [Motherhood and fatherhood through the prism of times and cultures]. Proceedings of the $9^{\text {th }}$ International Research Conference of the RAIZHI and IEA RAS. October 13-16, 2016 : in 2 vols. / ed. by N. L. Pushkareva and N. A. Mitsiuk. Moscow, Institut etnologii i antropologii im. N. N. Miklukho-Maklaia. Vol. I. 444 p. Pp. 29-31. (In Russ.).

Antonova, A. V. (2008) Osnovnye napravleniia pravovogo regulirovaniia polozheniia zhenshchin v Kitae: istoriia i sovremennost' [Primary areas of the legal adjustment of status of women in China: history and contemporaneity]. Vestnik NGU. Seriia: Istoriia, filologiia. Vol. 7, issue 4. Vostokovedenie, pp. 52-56. (In Russ.).

Aranchyn, Yu. L. (1977) RSTK i TNR [RSTK and TNR]. In: Velikii Oktiabr' i problemy noveishei istorii Tuvy [Great October and problems of the modern history of Tuva] / ed. by Yu. L. Aranchyn. Kyzyl, Tuvan book publishing house. 147 p. Pp. $72-89$. (In Russ.).

Bashkuev, V. Yu. (2018a) Traditsionnyi byt i problemy zdorov'ia mongol'skogo aratstva v 1920-1930-kh gg. (po arkhivnym materialam Narkomzdrava RSFSR) [Mongolian Livestock Breeders in the 1920s - 1930s: Traditional Lifestyles and Health Problems: A Case Study of Archived Records of the RSFSR People's Commissariat for Health)]. Oriental Studies, vol. 11(5), pp. 14-26. (In Russ.). DOI: https://doi.org/10.22162/2619-0990-2018-39-5-14-26

Bashkuev, V. Yu. (2018b) Mediko-sanitarnye ekspeditsii Narkomzdrava RSFSR v Tuvinskoi Narodnoi Respublike i stanovlenie tuvinskogo zdravookhraneniia (konets 1920-kh - seredina 1930-kh gg.) [Medical and sanitary expeditions of the People's Commissariat for Health of the RSFSR in the Tuvan People's Republic and the development of Tuvan healthcare in late 1920s - mid-1930s)]. Tomsk State University Journal, no. 426, pp. 52-63. (In Russ.). DOI: https://doi. org/10.17223/15617793/426/6

Biche-ool, S. M. (2018) Traditsionnye brachno-semeinye otnosheniya u tuvintsev i ikh transformatsiya $v$ sovetskii period [Traditional matrimonial and family relations among the Tuvans and their transformation during the Soviet era]. Abakan, Zhurnalist. 125 p. (In Russ.). 
Bobrovskaia, E. V. (2020) «Gosudarstvennyi feminizm» v SSSR: osobennosti gendernogo (ne) ravenstva v sovetskoi Rossii [State-approved feminism in the USSR: peculiarities of gender (in)equality in Soviet Russia]. Bulletin of the MSRU. Series: History and Political Sciences, no. 4, pp. 133-140. (In Russ.). DOI: https://doi.org/10.18384/2310676X-2020-4-133-140

Vainshtein, S. I. (1964) K istorii rannikh form razvitiia semeino-brachnykh otnoshenii (oitulaash u tuvintsev) [The history of the earliest forms of development matrimonial relations (oitulaash of the Tuvans)]. Sovetskaia etnografiia, no. 2 , pp. 123-124. (In Russ.).

Vladimirtsov, B. Ya. (1934) Obshchestvennyi stroi mongolov. Mongol'skii kochevoi feodalizm [The social system of the Mongols. Mongolian nomadic feudalism]. Leningrad, Izdatel'stvo Akademii Nauk SSSR. 224 p. (In Russ.).

Dorzhu, Z. Yu. (1993) Sotsial'noe polozhenie zhenshchin v Respublike Tuva. Istoriia i sovremennost' (1921-1993 gg.) [The social status of women in the Republic of Tuva. History and Modernity, 1921-1993]: Diss.... Doctor of History Moscow. 421 p. (In Russ.).

Dorzhu, Z. Yu. (2008) Zhenshchiny Tuvy: ot proshlogo k budushchemu [Women of Tuva: from the past to the future]. Kyzyl, TuvSU Publ. 184 p. (In Russ.).

Dorzhu, Z. Yu. (2011) Tuvinskaia sem'ia: Tendentsii ee zhiznedeiatel'nosti [Tuvan family: lifestyle trends]. Omskii nauchnyi vestnik, no. 1 (95), pp. 35-38. (In Russ.).

Zabelina, G. A. (2010) Zhenshchiny Tuvy v sem'e i obshchestve v pervoi polovine XX veka [Women of Tuva in the family and society in the first half of the twentieth century]. Kyzyl, TuvIKOPR SO RAN. 118 p.

Istoriia Tuvy [The History Of Tuva] (2007): in 3 vols. / ed. by V. A. Lamin. Novosibirsk, Nauka. Vol. 2. 430 p. (In Russ.).

Kliashtornyi, S. G. (1985) Raby i rabyni v drevnetiurkskoi obshchine (po pamiatnikam runicheskoi pis'mennosti Mongolii) [Male and female slaves in the ancient Turkic communities, from the monuments of Runic writing in Mongolia)]. In: Drevnie kul'tury Mongolii [Ancient Cultures of Mongolia] / ed. by R. S. Vasil'evskii. Novosibirsk, Nauka. 235 p. Pp. $159-168$.

Kon, F. Ya. (1934) Ekspeditsiia v Soiotiiu [An Expedition to Soyotia]. Za piat'desiat let [In fifty years]: in 3 vols. Moscow, Izdatel'stvo Vsesoiuznogo obshchestva politkatorzhan i ssyl'no-pereselentsev. Vol. 3. 296 p. (In Russ.).

Konstitutsii Tuvy [Constitutions of Tuva] (1999): a collection for the 55th anniversary of Tuva's accession to the USSR and RSFSR. Kyzyl, Tuvan book publishing house. 216 p. (In Russ.).

Mollerov, N. M. (2010) O periodizatsii noveishei istorii Tuvy s pozitsii teorii modernizatsii [On the periodization of the recent history of Tuva from the standpoint of modernization theory]. In: Sbornik materialov II Mezhd. nauchnoprakticheskoi konferentsii «Kochevye tsivilizatsii Tsentral'noi i Severnoi Azii: istoriia, sostoianie, problemy» [Proceedings of the $2^{\text {nd }}$ International Research Conference "Nomadic civilizations of Central and Northern Asia: history, state, problems"]. 01-04 June 2010 Krasnoyarsk State Pedagogical University named after V. P. Astafyev, Tyva State University. Krasnoiarsk, Izd-vo Krasnoiarskogo gosudarstvennogo pedagogicheskogo universiteta im. V. P. Astaf'eva. 360 p. Pp. 172-176. (In Russ.)

Mollerov, N. M. (2017) Istoriia Tuvy v 1920-t gg. skvoz' prizmu zhizni i deiatel'nosti starshego sovetnika tuvinskogo pravitel'stva i TsK TNRP P. S. Medvedeva [Senior Advisor to the Tuvan Government and the Central Committee of the Tuvan People's Revolutionary Party P. S. Medvedev: a History of Tuva in the 1920s through the Prism of His Life and Activities]. Oriental Studies, no. 3 (31), pp. 36-47. (In Russ.) DOI: https://doi.org/10.22162/2075-7794-2017-31-3-36-47

Mongush, M. V. (2010) Tuva vek spustia posle Karrutersa i Menkhen-Khel'fena [Tuva a century after Carruthers and Menchen-Helfen]. Osaka, National Museum of Ethnology. 212 p. (In Russ.)

Menkhen-Khel'fen, O. (2014) Puteshestvie v aziatskuiu Tuvu [A journey to Asian Tuva]. In: Uriankhai. Tyva depter [Uriankhai. Tuva notebooks]: in 7 vol./ comp. by S. K. Shoigu. Moscow, Slovo. Vol. 6. Tannu-Tuvinskaia Narodnaia Respublika (1921-1944 gg.) [Tannu-Tuva People's Republic (1921-1944)]. 584 p. Pp. 220-261. (In Russ.).

Murzova, O. M. and Zhiliaeva, M. S. (2018) Zhenshchina v politike i vlasti: sotsial'no-istoricheskii analiz [Women in Politics and Power: a socio-historical analysis]. In: Tekhnologii sotsial'noi raboty s raznymi gruppami naseleniia [Technologies of social work with different population groups]. Proceedings of the $7^{\text {th }}$ All-Russian Research Conference, December 4-7, 2018. ed. by M. S. Zhiliaeva. Chita, Zabaikal'skii gosudarstvennyi universitet. 109 p. Pp. 88-96. (In Russ.)

Potapov, L. P. (1969) Ocherki narodnogo byta tuvintsev [The Tuvans: sketches of the folk lifestyle and related household activities]. Moscow, Nauka, GRVL. 402 p. (In Russ.).

Pochekaev, R. Yu. (2018) Svedeniia rossiiskikh diplomatov KhVII v. o mongol'skom prave [Reports of $17^{\text {th }}$ century Russian diplomats on the Mongolian law]. In: Mongolica-XX [Mongolica-XX]. A collection of articles for the 200th anniversary of the founding of the Asian Museum / chairman of editorial board I. V. Kul'ganek. St. Petersburg, IV RAN. 104 p. Pp. $21-29$. (In Russ.)

Prokofieva, E. D. (1955) Nekotorye etnograficheskie dannye o tuvintsakh zapadnykh raionov Tuvinskoi avtonomnoi oblasti [Some ethnographical data about Tuvans in western regions of Tuva]. In: Kratkie soobshcheniia Instituta etnografii AN SSSR [Short reports of Institute of Ethnography]. Vol. 23. Pp. 3-18. (In Russ.)

Puteshestviia $v$ vostochnye strany Plano Karpini i Rubruka [Voyages to the Eastern Countries of Plano Carpini and Rubruk] (1957) / ed. by I. P. Shastina. Moscow, Gos. izdatel'stvo geograficheskoi literatury. 270 p. (In Russ.) 
Samdan, A. A. (2020) Vooruzhennoe vosstanie v Tuve v 1930 g. [Tuvan armed rebellion in 1930]. New Research of Tuva, no. 3, pp. 66-80. DOI: www.doi.org/10.25178/nit.2020.3.5

Serdobov, N. A. (1971) Istoriia formirovaniia tuvinskoi natsii [The history of the formation of the Tuvan nation]. Kyzyl, Tuvan book publisher. 482 p. (In Russ.).

Serdobov, N. A. (1985) Komintern i revoliutsionnaia Tuva [The Comintern and the revolutionary Tuva]. Kyzyl, Tuvan book publisher. 238 p. (In Russ.).

Temkina, A. A. (2004) Zhenskoe dvizhenie kak obshchestvennoe dvizhenie: istoriia i teoriia [Women's movement as a social movement: history and theory]. In: Gendernaia rekonstruktsiia politicheskikh sistem [Gender reconstruction of political systems] / ed. board: N. M. Stepanova and E. V. Kochkina. St. Petersburg, Institut gendernoi politiki. 991 p. Pp. 41-75. (In Russ.)

Tsyretarova, B. B. (2016) Bor'ba s sotsial'nymi bolezniami v Buriatii (1920-1940-ye gg.) [The fight against social diseases in Buryatia, 1920s - 1940s]. Vestnik Buriatskogo gosudarstvennogo universiteta, no. 1, pp. 29-35. (In Russ.) DOI: https://doi.org/10.18101/2306-753X-2016-1-29-35

Shostakovich, S. V. (2007) Politicheskii stroi i mezhdunarodno-pravovoe polozhenie Tannu-Tuvy v proshlom i nastoiashchem [The political system and the international legal situation of Tannu-Tuva in the past and present]. In: Uriankhai. Tyva depter [Uriankhai. Tuva notebooks]: in 7 vol. / comp. by S. K. Shoigu. Moscow, Slovo. Vol. 6. Tannu-Tuvinskaia Narodnaia Respublika (1921-1944 gg.) [Tannu-Tuva People's Republic (1921-1944)]. 584 p. Pp. 182-218. (In Russ.) 